\title{
Characterization of the Population Affiliated to the Subsidized Health Insurance Scheme in Colombia. A Systematic Review and Meta Analysis.
}

\author{
Laura Mora Moreo \\ Colombian Agency of Health Technology Assessment \\ Kelly Estrada-Orozco ( $\nabla$ kelly.estrada@iets.org.co) \\ Colombian Agency of Health Technology Assessment \\ Oscar Espinosa \\ Colombian Agency of Health Technology Assessment \\ Lorena Mesa-Melgarejo \\ Colombian Agency of Health Technology Assessment
}

systematic-review

Keywords: Social Determinants of Health, Global Health, Public Health, Epidemiologic Factors, Epidemiology

Posted Date: January 28th, 2022

DOI: https://doi.org/10.21203/rs.3.rs-1285018/v1

License: () (1) This work is licensed under a Creative Commons Attribution 4.0 International License. Read Full License 


\section{Abstract}

Background: Some reports suggest differences regarding health needs between the population affiliated to subsidized health insurance scheme (SS) compared to the contributory health insurance scheme (CS) in Colombia. Therefore, the objective of this study was to identify the epidemiological profile of the population affiliated to the SS in Colombia, to establish if there are differences compared to CS in terms of: incident diseases, prevalent diseases, and use of health services and to estimate the magnitude of the differences from statistical analyzes of the data retrieved in a systematic review of data published in the literature and other sources of information.

Methods: Following the Preferred Reporting Items for Systematic Reviews and Meta-Analysis (PRISMA) methodology. The search was made from 1993, with none other restriction. The information was synthesized in five categories according to the most important risk populations. We estimated combined incidences from epidemiological surveillance data, prevalence ratio, and other measures to estimate the difference between the studied groups. A $95 \%$ interval confidence was considered. A random effects models were used weighted by the inverse of the variance of the cumulative incidence calculated for each disease. The risk of bias was assessed using Joanna Briggs Institute critical appraisal tools.

Results: 16.236 we identified, 14.972 were exclude after the title and abstract screening, 725 articles were verified as full text and finally 268 articles were included. The relative risk for non-communicable and communicable diseases was lower in the SS than the RC (RR: 0,37 and 0,72 respectively, p-value <0,05), however, for the other three categories, differences were found, the risk of presenting obstetric and maternal conditions in the SS versus the CS was RR 1,55 , for frequent conditions during early childhood and other diseases was RR 1,28 with p-value $<0,05$ respectively. The use of health services was different by scheme, finding less demand, access, or provision in health services in the SS.

Conclusions: This study allowed to conclude that there are differences in the incidence, prevalence, and use of health services between health affiliation scheme (SS and CS) in Colombia allowing to guide decision-making to stakeholders.

Registration: PROSPERO Registration number CRD42021279234.

\section{Background}

The General System of Social Security in Health (SGSSS) in Colombia is the mechanism by which the public health service is regulated and creates the conditions for the access of the population to all levels of health care, this system is integrated by the State through the Ministry of Health and Social Protection (MHSP) and other government entities; began its regulation through the Law 100 of 1993, which is the current comprehensive social security system in the country (1). This law, in order to guarantee access to health care, established that for each affiliated person a Capitation Payment Unit (CPU) is recognized for Health Promoting Entities (HPE) (2). The CPU is defined as the annual value recognized by each person affiliates to the SGSSS to cover the benefits included in the Health Benefit Plan (HBP). Likewise, Law 100 of 1993 stipulated an insurance system by schemes that includes the contributory scheme (CS) and the subsidized scheme (SS) (3).

All persons linked through a labor contract, public servants, pensioners and independent workers with the ability to pay can join the CS who, through a monthly contribution to an HPE, access health services through Health Service Provider Institutions (HSPI). The people affiliated with this scheme can be dependent or independent workers with income, who can guarantee the monthly contributions and in turn the additional payments that must be made in health matters, such as moderating fees and copayments - these payments being proportional to the income of each person (1).

On the other hand, the subsidized scheme is characterized by affiliating people without the ability to pay and vulnerable in the country, that is, those classified as level 1 or 2 in the Beneficiary Selection System (BSS) and priority special populations such as people in forced displacement, abandoned child population, boys and girls disconnected from the armed conflict, indigenous communities, elderly people in protection centers, people from the witness protection program, street dwellers and Rom peoples, among others (according to classification 3 of the BSS). This population can also choose the HPE that provides health care services through an HSPI (1)(4).

Currently, the value of the financing that is allocated for health coverage in each of the scheme is different, as is provided in Resolution 2503 of 2020 , which assigns the budget for the CPU for the year 2021 according to the scheme, either contributory or subsidized. The CPU estimate is the product of the technicalactuarial analysis of the information reported by the HPE to the Ministry of Health, where the main frequencies of use of the health services provided are identified. It is important to note that the quality of the information of the CS is superior to the SS. Additionally, government certified sources are taken into account to consider factors such as: demographic changes in the relevant population, the national epidemiological profile, health technologies available in the country, general illnesses and maternal conditions covered in the promotion of health and prevention phases of the disease and the prevention, diagnosis and treatment of pathologies according to the use of services and levels of care and complexity. Particular characteristics of population subgroups such as the indigenous population are also taken into account, for whom a different percentage of CPU is available due to their sociocultural, demographic and epidemiological differences (5).

The analysis of these characteristics to define the monetary values of the CPU for each scheme is carried out in order to collect the differences that may occur in the risk of becoming ill and to present differential health results in the affiliated population. These differences, which are tangible especially in health outcomes, have been described in the SGSSS in Colombia. The Ministry of Health in 2015 demonstrated the inequities in health in the country in terms of mortality, as well as a possible relationship of this with the population density indices. This analysis also evidenced a positive correlation between infant mortality rates and socioeconomic inequity, observing that the departments that presented improvements in the Gini coefficient maintained lower levels in those rates (6). 
Other differences in the consumption of health resources and in the presentation of communicable diseases have also been reported. Mejía et al. (7), published an analytical study that analyzed the equity in access to health services in the department of Antioquia, as well as its main determinants, finding that education, age and type of affiliation to social security were the main factors that determine the access to preventive and curative services. On the other hand, Hilarion-Gaitán et al. (8), evaluated social inequalities in health in Colombia, using the type of affiliation to the health system as a representative parameter of the socioeconomic condition, for this, they carried out a descriptive and retrospective study where the incidence rates for events were calculated. In the SS population, 82.31 more cases of Plasmodium falciparum malaria were reported per 100,000 affiliates than those reported in the CS, additionally, belonging to the SS was associated with a greater risk of dying from malnutrition in children under five years of age, specifically 31.74 times more compared to CS.

Although there are some reports and seminal studies that suggest that may be different health needs in the population affiliated to the SS compared to the needs of the CS in Colombia, determined by differences in the burden of disease, health outcomes and use of health services, it has not been proven whether these differences exist across the spectrum of diseases, nor is the magnitude of these dissimilarities recognized. Therefore, the objective of this study was to identify the epidemiological profile of the population affiliated to the SS in Colombia, establish if there are differences compared to CS in terms of: incident diseases, prevalent diseases and use of health services and estimate the magnitude of differences from statistical analyzes of data retrieved in a systematic review of data published in the literature and other sources of information.

\section{Methods}

The protocol for this systematic review (SRL) was registered on PROSPERO prior to starting the literature search CRD42021279234. A systematic and exhaustive literature search was carried out. The entire process followed the international quality standards used by the Cochrane Collaboration (9). The review was guided by the following research question: What is the epidemiological profile and the features of use of health services for the population affiliated to the SS of Colombia?

We took into count, all the population linked to the SS as our target population and the main outcomes assessed were I). the epidemiological profile of transmissible diseases, non-transmissible diseases, obstetric and maternal conditions, frequent conditions during early childhood and other conditions (external causes), and II). use of health services.

\section{Inclusion and exclusion criteria}

The search and selection of studies and other documents was guided by the elements of the structured question. All documents that presented information on: i) population affiliated to the SS in Colombia, ii) data such as incidence, prevalence, absolute and relative distribution of communicable and noncommunicable diseases, other conditions or pathologies, use of health services, iii) exclusive information on the subsidized scheme or comparative analysis against CS were included. This SRL was not limit by language or type of study, and the timeframe considered was from 1993 to 2021.

\section{Search strategy}

Four bibliographical databases (Medline, Embase, Scielo and LiLacs) were systematically searched for studies published between January 1993 and September 2021. The threshold was considered from 1993 due from that date was issued the Law 100 regarding the classification by health scheme in Colombia.

Relevant literature was identified following search algorithms summarized in Supplementary table 1. MeSH, Emtree y DeCS term were use such "'"epidemiology", "health insurance", "subsidized”, "subsidized health insurance scheme", "regimens". Additionally, a non-indexed data search was performed in 22 web sites related to this topic (table 1). Studies identified through each database were imported to Mendeley, and then duplicates were identified and removed. The studies were then imported to Rayyan.

\section{Study selection}

The title and abstract screening were reviewed by one author (LMM) and was verified by a second independent reviewer (KEO); disagreements were resolved by consensus.

Those studies that met the eligibility criteria previously described were included. The full text screening was carried out independently by two reviewers (LMM and KEO). Disagreements were resolved by consensus. The complete screening and selection process used was presented using the flow diagram proposed by the PRISMA statement (10).

\section{Data extraction}

The relevant data for this systematic review were extracted by a reviewer (LMM) and independently verified by a second reviewer (KEO), using a data extraction form designed in Excel, which was adjusted after the pilot extraction carried out with two of the articles. The information was extracted prioritizing studies with a cohort-type epidemiological design, cases and controls, prevalence, and descriptive observational ones. Subsequently, the information was extracted from documents and reports of epidemiological surveillance reports and finally, the documents from repositories of academic databases and gray literature.

\section{Quality assessment}


The quality assessment was conducted by reviewing each study according to critical appraisal tool made by the Johana Briggs Institute (11). These tools assess focus in different aspects such; (i) type of design; (ii) how outcome variables were assessed; and (iii) if confounding variables were controlled. Quality assessment was performed by one researcher (LMM). Consensus was reached in consultation with a second author (KEO) as needed.

\section{Analysis of the systematized papers}

The synthesis of the information of all the included studies and documents was carried out in a descriptive way, additionally, synthesis tables were elaborated for the relative frequency measures (incidence and prevalence) or absolute frequency reported in them. The incidences of health conditions were calculated according to five categories of interest: non-communicable diseases, communicable diseases, maternal and obstetric conditions, early childhood health conditions and other diseases not classified in the previous ones. For each category the following operational definition was used (additional file 1, table 1):

Non-communicable diseases: They result from the combination of genetic, physiological, environmental, and behavioral factors.

Communicable diseases: They are contagious or infectious diseases, caused by specific infectious agents or their toxic products in a susceptible host.

Maternal and obstetric conditions: They are a set of physiological events and pathophysiological alterations that affect women in reproductive age, including the prenatal, natal, and postnatal periods.

Common conditions in early childhood: Group of diseases that occur frequently in boys and girls from 0 to 5 years old. In this group of diseases, perinatal conditions and congenital defects are considered.

Other diseases: It refers to external causes such as accidents, trauma, poisoning, and other events that affect the integrity and health of people, which are not related to the health conditions already mentioned.

The information was presented summarized according to the disease group analysis categories and the distribution of health services uses, according to the affiliation scheme. For some absolute frequencies reported in surveillance systems, the incidence estimator was calculated using as denominator the population affiliated to the CS or the SS according the study period, for example: the report of infection by the human immunodeficiency virus (HIV) reported in 2020 there were 5.167 cases belonging to the SS where the affiliated population for this scheme in the same year was 24.307 .637 people, while the number of cases reported in the SC was 6.213 out of a total of affiliates of 21.796 .582 . The affiliates by scheme were obtained from the Unique Affiliate Database (UAD) (12).

On the other hand, combined incidence estimation were generated from data from epidemiological surveillance systems at the national level, using metaregressions taking into account a $95 \%$ confidence interval. In addition, random effects models were used weighted by the inverse of the variance of the cumulative incidence calculated for each pathology and each period of time to the report, considering the high expected heterogeneity due to: incidence estimators for different health conditions grouped in five categories of analysis (noncommunicable diseases, communicable diseases, maternal and obstetric conditions, early childhood health conditions and other diseases not classified in the above) and different observation periods (13-15). The heterogeneity values were confirmed by calculating the $\mathrm{I}^{2}$ estimate. These results are summarized in "forest plot" graphics. In total, 10 models were built using the statistical software STATA 14 (16).

For health services, the frequencies of use of health services were calculated for the people affiliated with each scheme, the SS prevalence ratio between the $\mathrm{CS}$ and the odds ratio as a measure of association.

\section{Results}

\section{Literature search results}

In the indexed databases consulted, a total of 5,235 references were found and 11,001 references were found in gray literature and official sources such as web pages of official national institutions, repositories of universities and non-profit organizations. The detail of the search results is presented in Table 1.

Table 1. References found in gray literature and official sources 


\begin{tabular}{|c|c|c|}
\hline $\mathbf{N}^{\circ}$ & Databases & Results \\
\hline 1 & Ministry of Health and Social Protection & 663 \\
\hline 2 & National Administrative Department of Statistics & 4 \\
\hline 3 & Google scholar & 400 \\
\hline 4 & Interagency Coordination Platform for Refugees and Migrants from Venezuela - R4V & 88 \\
\hline 5 & Institutional Repository University of Antioquia & 241 \\
\hline 6 & Institutional Repository University Nacional & 663 \\
\hline 7 & Institutional Repository Pontificia University Javeriana & 496 \\
\hline 8 & Institutional Repository University of Andes & 1.253 \\
\hline 9 & Institutional Repository University of Bosque & 62 \\
\hline 10 & Institutional Repository University of Rosario & 1.423 \\
\hline 11 & National Institute of Health & 2.010 \\
\hline 12 & Colombian Association of Comprehensive Medicine Companies & 48 \\
\hline 13 & Foundation for Higher Education and Development & 4 \\
\hline 14 & Foundation for Research and Development of Health and Social Security & 11 \\
\hline 15 & Colombian Association of Hospitals & 20 \\
\hline 16 & Office of the General Comptroller of the Republic & 400 \\
\hline 17 & National Superintendency of Health & 3.062 \\
\hline 18 & Vital Return & 3 \\
\hline 19 & Econometrics Consultants & 2 \\
\hline 20 & Ombudsman's Office & 50 \\
\hline 21 & High-Cost Account & 5 \\
\hline 22 & Bank of the Republic & 10 \\
\hline 23 & Center for Studies in Social Protection and Health Economics & 29 \\
\hline 24 & Inter-American Development Bank & 33 \\
\hline 25 & World Bank & 21 \\
\hline
\end{tabular}

Of the 16,236 references found, 529 were excluded because they were duplicates, 15,707 were screened by title and abstract, and 735 references were evaluated in full text. Finally, 268 documents were included (see Additional file 1. Table 2-3). The information flowchart is detailed in the PRISMA Figure 1.

The included studies contain information from 1993 to 2021; 42 articles were obtained from indexed databases (17-58). Of these, four have a retrospective design $(23,24,46,55)$, two are case series $(32,49)$, one case-control study $(31)$, five cohort studies $(21,30,45,47,56)$, 27 prevalence studies (cross sectional) $(17,20,22,25-29,33-42,44,48,50-52,57-59)$, one descriptive study (18) and two studies ecological $(43,54)$. Through google Scholar, 21 references ((60-79), 156 annual reports from the Colombian National Institute of Health INS (80-102,102-108,108-210), two reports from R4V (211,212), a report from the website of the Ministry of Health and Social Protection were included (213), and two from the High Cost Account page (214,215). The selected references whose source were the academic repositories of the Colombian universities were 44; 23 from the National University of Colombia (74,216-237), 11 from the University of Rosario (87,89,157,238-245), 3 from the University of Antioquia (246-248), 3 from the University of Andes (249-251), 2 from the University of Bosque $(252,253)$, and 2 from the University Javeriana $(254,255)$.

Of the documents found, 162 came from public sources and 106 from private sources. Regarding the type of document, three were poster summaries, 65 articles, 3 report summaries of notification events in power point format, 6 technical reports of outbreak studies, 22 infographics, 129 reports of epidemiological surveillance events, 2 press reports, 38 academic thesis. The references that contained information at the national level were 193,75 at the regional, departmental, or municipal level. Among the main cities described in the analyzed documents are Bogotá, Barranquilla, Medellín, Cali, Tunja, Cartagena, Chocó, Guainía, Pasto, Popayán, Santander, Villavicencio, Manizales, Bucaramanga, and Pereira.

The number of documents and references according to the category of analysis: health condition and use of health services, is presented in Table 2 .

Table 2. Bibliographic references for each category 


\begin{tabular}{|c|c|c|}
\hline $\begin{array}{l}\text { Category of } \\
\text { analysis by } \\
\text { health } \\
\text { condition or } \\
\text { use of health } \\
\text { services }\end{array}$ & $\begin{array}{l}\text { Number of } \\
\text { documents } \\
(\%) \\
\mathrm{N}=268\end{array}$ & References \\
\hline $\begin{array}{l}\text { Non- } \\
\text { communicable } \\
\text { diseases }\end{array}$ & $60(22.4)$ & $\begin{array}{l}(17,21,26,27,29,30,33,41,44,45,47,57,65,66,68,71,73,74,74,79,84,86,90,128,130,143,166,175,179,183,188,199,203,209,216,22 \\
233,248,250,252,254,256-267)\end{array}$ \\
\hline $\begin{array}{l}\text { Communicable } \\
\text { diseases }\end{array}$ & $129(48.1)$ & $\begin{array}{l}(8,24,32,34,38,39,49,51-54,56,60-62,76,77,80-83,88,91,93,95,96,98-106,110-124,126,127,129,132,133,135,137-140,144, \\
156,158-161,163,172,173,177,178,182,184,185,187,189,191,194-198,200,201,204,207,210,220,223,237,241,249,251,255,2\end{array}$ \\
\hline $\begin{array}{l}\text { Maternal and } \\
\text { obstetric } \\
\text { conditions }\end{array}$ & $26(9.7)$ & $(48,72,102,102,107,108,108,109,150,157,168,169,197,197,217,224,230,242,246,247,289-293)$ \\
\hline $\begin{array}{l}\text { Common } \\
\text { conditions in } \\
\text { early } \\
\text { childhood }\end{array}$ & $17(6.3)$ & $(40,46,70,75,94,97,131,164,170,180,193,218,221,294-297)$ \\
\hline $\begin{array}{l}\text { Other diseases } \\
\text { (external } \\
\text { causes) }\end{array}$ & $11(4.1)$ & $(64,136,186,192,234,298-300)$ \\
\hline Health services & $25(9.3)$ & $(18,22,25,36,37,42,44,58,59,63,67,78,211-213,226,228,229,235,238,245,253,301-303)$ \\
\hline
\end{tabular}

\section{Behavior of the disease according to the subsidized and contributory scheme in Colombia}

\section{Non-communicable diseases}

Incidence data were collected from reports from the National Institute of Health (INS) for mandatory notification events classified as noncommunicable diseases: cancer, rheumatoid arthritis, transplants (kidney, heart, liver, lung), rare diseases, malnutrition, and exposure to fluorine.

The data related to the incidence of the disease were 17 reports $(143,166,175,188,203,209,214,215,259-261)$ and 34 to data on the distribution of diseases in morbid groups of patients $(15,18,44,54,62,63,65,68,70,71,71,76,23,81,83,87,126,128,24,177,181,186,188,197,214,217,220,27,223,225,229-$

$231,237,242,246,248,250,30,252,254-261,37,38,41,42)$.

\section{Communicable diseases}

INS reports were the main source of information for this category, including data on diseases such as ophidian accidents, attacks by animals transmitting rabies, acute chagas, chronic chagas, chikungunya, dengue, chickenpox, malaria, diphtheria, equine encephalitis, meningococcal disease, yellow fever, typhoid and paratyphoid fever, hepatitis B, hepatitis A, infections associated with medical-surgical procedures, acute respiratory infections, leishmaniasis, leprosy, leptospirosis, bacterial meningitis, acute flaccid paralysis, mumps, congenital rubella, measles, congenital syphilis, Accidental tetanus, whooping cough, tuberculosis, HIV AIDS, Zika. 78 documents were included. $(9,21,52,199,202,205,206,208,218,221,262-269,270-273,58,59,77-79,29,80,85,88,90,92,93,95-$ $98,31,99,101-104,108-112,35,113-120,120,121,36,122,124,125,127,130-133,135,136,46,137,138,142-147,149,150,49,151-154,154,156-$ $160,50,161,165,170,171,175,176,180,182,183,51,185,187,189,192-196,198,199)$ and 15 studies offered information on the distribution of the population in the subsidized scheme $(32,51,56,60,76,77,148,154,223,237,241,249,251,255,287)$.

\section{Maternal and obstetric conditions}

For the conditions that affected women in a fertile state, 10 studies were taken into account that indicated the incidence of the following alterations: gestational syphilis, maternal mortality and extreme maternal morbidity $(69,148,166,167,189,195,195,195,99,228,244,245,100,105,105,106,106,107,148)$; and seven $(48,157,217,224,242,293)$ showing the distribution of their population according to the affiliation scheme (CS and SS).

\section{Common conditions in early childhood}

This category included 11 references, nine from INS reports, and two articles resulting from indexed databases $(168,178,191,219,276,277,72,91,94,129,162)$, reporting incidences of health conditions and early childhood illness as outcomes such as: underweight at birth, perinatal mortality, late neonatal mortality and congenital malformations. Five studies showed the distribution of their population for SS and CS $(40,46,70,218,221)$.

\section{Other diseases}

For the category "other diseases", 11 references were considered, of which nine came from INS reports $(82,134,174,184,190,200)$ and two results from other sources $(64,234)$. The incidence of cases of pathologies was taken into account: violence from gender and domestic violence, external causes due to aesthetic procedures and consumption accidents, intoxications, sexual abuse and maxillofacial trauma.

\section{Subsidiary scheme}

\section{Non-communicable diseases}


The noncommunicable diseases that had the highest incidence during the observation period (2016-2021) were cancer (all types) for the year 2020. Heart, lung, and kidney transplants with living donors were the least incidents. Details of the data can be found in additional file 2 -Table 1.

The combined measure of cumulative incidence for non-communicable diseases in Colombia in the SS during the aforementioned time period was 0.000197 ( $95 \%$ Cl: 0.000191 to 0.000203 ). The details of the accumulated incidents by affiliation scheme are presented in Table 3 and their graphic representation in the forest plot of additional file 2 - Illustration 1.

Table 3. Cumulative incidence for diseases and other health conditions in Colombia by affiliation scheme during the years 2016-2021

\begin{tabular}{|c|c|c|c|c|c|c|c|c|}
\hline \multirow{3}{*}{$\begin{array}{l}\text { Categories } \\
\text { Non-communicable diseases }\end{array}$} & \multicolumn{3}{|c|}{ Subsidiary scheme } & \multicolumn{3}{|c|}{ Contributive scheme } & \multicolumn{2}{|c|}{ SS/CS } \\
\hline & \multirow{2}{*}{$\begin{array}{l}\begin{array}{l}\text { Cumulative } \\
\text { incidence }\end{array} \\
0,000197\end{array}$} & \multicolumn{2}{|c|}{$\begin{array}{l}95 \% \text { confidence } \\
\text { interval }\end{array}$} & \multirow{2}{*}{$\begin{array}{l}\text { Cumulative } \\
\text { incidence }\end{array}$} & \multicolumn{2}{|c|}{$\begin{array}{l}95 \% \text { confidence } \\
\text { interval }\end{array}$} & \multicolumn{2}{|l|}{$\begin{array}{l}\text { Relative } \\
\text { Risk RR }\end{array}$} \\
\hline & & 0,000191 & 0,000203 & & 0,000506 & 0,000546 & 0,374000 & 0,000000 \\
\hline Communicable diseases & 0,000124 & 0,000120 & 0,000127 & 0,000171 & 0,000165 & 0,000177 & 0,725146 & 0,000000 \\
\hline $\begin{array}{l}\text { Maternal and obstetric } \\
\text { conditions }\end{array}$ & 0,000166 & 0,000131 & 0,000201 & 0,000107 & 0,000088 & 0,000127 & 1,551402 & 0,000000 \\
\hline $\begin{array}{l}\text { Common conditions in early } \\
\text { childhood }\end{array}$ & 0,061682 & 0,060620 & 0,062744 & 0,048309 & 0,047478 & 0,049141 & 1,277000 & 0,000000 \\
\hline $\begin{array}{l}\text { Other diseases (external } \\
\text { causes) }\end{array}$ & 0,000397 & 0,000374 & 0,000420 & 0,000309 & 0,000284 & 0,000333 & 1,284790 & 0,000000 \\
\hline
\end{tabular}

SS: subsidized scheme, CS: contributory scheme

From the studies that described the frequency distribution of non-communicable diseases according to the affiliation scheme and that were published between 2004-2020, information was obtained on different types of cancer, high blood pressure, asthma, cardiovascular diseases, chronic skin diseases, autoimmune joint inflammatory diseases, nutritional deficiencies, and diseases of the oral cavity. The conditions whose number of cases in the SS was higher due to those in the CS were breast cancer, chronic diseases in general, and epilepsy. Details are presented in additional file 3 , table 1.

\section{Communicable diseases}

For this category, 78 documents were considered between reports and studies. 32 pathologies were included, for the observation period 2012 to 2021 chickenpox and chikungunya the highest incidence and neonatal tetanus and diphtheria the lowest incident cases (additional file 2 - Table 2 ). The cumulative incidence for SS was 0.000124 ( $95 \% \mathrm{Cl}: 0.000120$ to 0.000127 ). The details of the cumulative incidences by affiliation scheme are presented in Table 3 and their graphic representation in the forest plot of additional file 2- Illustration 2.

From the studies that described the frequency distribution of communicable diseases according to the affiliation scheme and that were published between 2011-2021, information was obtained on vector-borne diseases, acute respiratory infection, tuberculosis, sexually transmitted infections and intestinal parasitic infection. Except for acute respiratory infection, multidrug-resistant tuberculosis, and Zika, all the other communicable conditions had a greater number of cases in the SS than the number of CS cases in the cohorts studied. The conditions with the highest ratio SS / CS were chagas disease, congenital syphilis and gestational syphilis. Details are presented in table $4 .(32,51,56,60,76,77,148,154,223,237,241,249,251,255,287)$.

Table 4. Distribution of cases by scheme in morbid cohorts of communicable diseases between 2011-2021 


\begin{tabular}{|c|c|c|c|c|c|c|}
\hline Author, year & Health condition & Data source & $\begin{array}{l}\text { Cases } \\
\text { SS }\end{array}$ & $\begin{array}{l}\text { Cases } \\
\text { CS }\end{array}$ & Total & $\begin{array}{l}\text { Ratio } \\
\text { SS/CS }\end{array}$ \\
\hline Curtidor, 2016(77) & Tuberculosis & TB control follow up program & 22 & 203 & 225 & 0,1 \\
\hline Urrego, 2019(251) & Acute respiratory infections & National Demographic and Health Survey & 171.051 & 736.746 & 915.942 & 0,2 \\
\hline Nuñez, 2017(223) & Acute respiratory infections & $\begin{array}{l}\text { National Administrative Department of } \\
\text { Statistics }\end{array}$ & 23.061 & 72.493 & 106.764 & 0,3 \\
\hline Ruiz, 2017(249) & Zika & SIVIGILA & 126 & 279 & 2.325 & 0,5 \\
\hline INS, 2018(154) & Acute chagas & INS & 9 & 8 & 822 & 1,1 \\
\hline Paniagua, 2021(56) & Tuberculosis & SIVIGILA & 3.215 & 3.032 & 6.739 & 1,1 \\
\hline Angel, 2012(60) & sexually transmitted diseases & $\begin{array}{l}\text { Profamilia, Hospital of Fontibón, Hospital of } \\
\text { Engativá }\end{array}$ & 637 & 485 & 1.444 & 1,3 \\
\hline Quintero, 2011(255) & sexually transmitted diseases & National Health Survey & 12.603 & 9.484 & 29.760 & 1,3 \\
\hline Ettenger, 2014(51) & HIV & National Demographic and Health Survey & 3.603 & 2.755 & 10.596 & 1,3 \\
\hline Gomez, 2019(237) & HIV & High Cost Account & 14.758 & 8.807 & 23.803 & 1,7 \\
\hline $\begin{array}{l}\text { Bouwmans, } \\
2016(241)\end{array}$ & Intestinal parasitic infection & Community & 121 & 69 & 190 & 1,8 \\
\hline Zabaleta, 2019(32) & Tuberculosis & National Reference Laboratory & 32 & 17 & 51 & 1,9 \\
\hline Agudelo, 2016(148) & $\begin{array}{l}\text { Congenital and Gestational } \\
\text { Syphilis }\end{array}$ & SIVIGILA & 48 & 10 & 71 & 4,8 \\
\hline INS, 2018(287) & Chronic chagas & INS & 341 & 33 & 388 & 10,3 \\
\hline Echavez, 2018 (76) & Congenital syphilis & SIVIGILA & 741 & 45 & 845 & 16,5 \\
\hline
\end{tabular}

SS: Subsidized scheme, CS: Contributory scheme, HIV: human immunodeficiency virus, TB: tuberculosis, INS: National Institute of Health, SIVIGILA: Public Health Surveillance System

\section{Maternal and obstetric conditions}

The INS was the main source of information for this category, taking incident data from conditions such as extreme maternal morbidity between the years 2018 to 2021 . Of the total of 10 reports included, extreme maternal morbidity was the condition with the highest incidence and maternal mortality was the one with the lowest incidence (Additional file 2 - Table 3). The pooled incidence measure for SS was 0.000166 (95\% Cl: 0.000131 to 0.000201 ). The details of the accumulated incidents by affiliation scheme are presented in Table 3 and their graphic representation in the forest plot additional file 2 -Illustration 3.

From the studies that described the frequency distribution of obstetric and maternal conditions according to the affiliation scheme and that were published between 2016-2021, it can be observed that the conditions whose number of cases in the SS was higher due to those in the CS were maternal mortality and extreme maternal morbidity $(48,157,217,224,242,293)$ those details are presented in Table 5.

Table 5. Distribution of cases by scheme in morbid cohorts of obstetric and maternal conditions, 2016-2021

\begin{tabular}{|c|c|c|c|c|c|c|}
\hline Author, year & Health condition & Data source & $\begin{array}{l}\text { Cases } \\
\text { SS }\end{array}$ & $\begin{array}{l}\text { Cases } \\
\text { CS }\end{array}$ & Total & $\begin{array}{l}\text { Ratio } \\
\text { RS/RC }\end{array}$ \\
\hline Salazar, 2017(217) & $\begin{array}{l}\text { Extreme maternal } \\
\text { morbidity }\end{array}$ & SIVIGILA & 363 & 956 & 1.384 & 0,38 \\
\hline Yepes, 2016(293) & $\begin{array}{l}\text { Extreme maternal } \\
\text { morbidity }\end{array}$ & Second and third level institutes & 340 & 485 & 1.011 & 0,7 \\
\hline Arocha, 2021(157) & $\begin{array}{l}\text { Prenatal care, } \\
\text { breastfeeding }\end{array}$ & Comunity & 536 & 360 & 1.416 & 1,49 \\
\hline $\begin{array}{l}\text { Álvarez-Sierra, } \\
2020(48)\end{array}$ & Maternal mortality & National Administrative Department of Statistics & 28 & 18 & 49 & 1,56 \\
\hline Solarte, $2017(242)$ & $\begin{array}{l}\text { Extreme maternal } \\
\text { mortality }\end{array}$ & Hospital “la samaritana" & 64 & 15 & 95 & 4,27 \\
\hline Soto, 2016(224) & Maternal mortality & SIVIGILA & 15 & 1,1 & 22 & 13,4 \\
\hline Ayala, 2015(40) & Prenatal care & $\begin{array}{l}\text { Individual Service Provision Registry (ISPR) and vital } \\
\text { records }\end{array}$ & 49.300 & 35.700 & 85.000 & 1,4 \\
\hline Catalan, 2010(46) & Perinatal death & Health providing institutions & 3 & 1 & 7 & 3 \\
\hline
\end{tabular}

SS: Subsidiary scheme, CS:Contributory scheme, SIVIGILA: Public Health Surveillance System, ISPR: Individual Service Provision Registry

\section{Common conditions in early childhood}


For this category, the information was obtained from nine INS reports and two studies from other sources $(168,178,191,219,276,277,72,91,94,129,162)$. Congenital malformations were the pathology with the largest new cases. The result of the combined incidence measure was 0.061682 ( $95 \% \mathrm{Cl}$ : 0.060620 to 0.062744 ) for the SS. The details of the cumulative incidences by affiliation scheme are presented in Table 3 and their graphic representation in the forest plot additional file 2 - Illustration 4 . Of the studies that described the frequency distribution of non-communicable diseases according to the affiliation scheme and that were published between 2014-2016, information was obtained on infant death and congenital malformations, with a ratio of 2.1 to 1 of cases in the SS with respect to the CS $(70,218,221)$. Details are presented in table 6.

Table 6. Distribution of cases by scheme in morbid cohorts of common conditions in early childhood, 2014-2016

\begin{tabular}{|c|c|c|c|c|c|c|}
\hline Author, year & Health condition & Data source & $\begin{array}{l}\text { Cases } \\
\text { SS }\end{array}$ & $\begin{array}{l}\text { Cases } \\
\text { CS }\end{array}$ & Total & $\begin{array}{l}\text { Ratio } \\
\text { RS/RC }\end{array}$ \\
\hline Romero, 2017(218) & Children mortality & Community & 30.402 & 71.852 & 102.254 & 0,4 \\
\hline Murica, 2014(70) & $\begin{array}{l}\text { Congenital } \\
\text { malformations }\end{array}$ & Third level institutions & 246 & 115 & 416 & 2,1 \\
\hline $\begin{array}{l}\text { Cordoba, } \\
2016(221)\end{array}$ & Children mortality & $\begin{array}{l}\text { National Administrative Department of } \\
\text { Statistics }\end{array}$ & 396.561 & 48.265 & 444.826 & 8,2 \\
\hline
\end{tabular}

SS: Subsidiary scheme, CS:Contributory scheme

\section{Other diseases}

This category was constituted with information from 11 references. nine from the INS between 2018 and 2021 and two studies published in 2015 and 2017 from the literature. For the SS, sexual abuse and intrafamily and gender violence were the most incident events and injuries from external causes caused by accidents related to the consumption of psychoactive substances and aesthetic procedures the least incidents (Additional file 2 -Table 5). The cumulative incidence for this scheme was 0.000397 ( $95 \% \mathrm{Cl}: 0.000374$ to 0.000420 ). The details of the accumulated incidents by affiliation scheme are presented in Table 3 and their graphic representation in the forest plot Additional file 2 - Illustration 5.

\section{Contributory scheme}

\section{Non-communicable diseases}

For CS, the non-communicable diseases with the most incidents were cancer and rheumatoid arthritis, and the least incidents were kidney and pancreas transplantation and lung transplantation. The cumulative incidence was 0.000526 ( $95 \% \mathrm{Cl}: 0.000506$ to 0.000546 ). The details of the cumulative incidences by affiliation scheme are presented in Table 3 and their graphic representation in the forest plot Additional file 2- Illustration 6.

From the studies that described the frequency distribution of non-communicable diseases according to the affiliation scheme and that were published between 2004-2020, it is evidenced that dental conditions, cancer and cerebrovascular disease presented a lower number of cases for CS than for the SS (additional file 2 - Table 1).

\section{Communicable diseases}

Of the 32 pathologies analyzed during the observation period 2012 to 2021 , the cumulative incidence for CS was 0.000171 ( $95 \%$ Cl: 0.000165 to 0.000177 ) additional file 2 - Table 2. Being chickenpox, malaria and dengue, the diseases with the highest incidence; and acute chagas and equine encephalitis the least incidents. The details of the accumulated incidences by affiliation scheme are presented in Table 3 and their graphic representation in the forest plot Additional file 2 -Illustration 7.

Among the documents that characterized the distribution of pathologies by scheme, it was found that multidrug-resistant tuberculosis and acute respiratory infections presented a higher ratio of cases with respect to SS (see Table 4).

\section{Obstetric and maternal conditions}

For this scheme, the most incident obstetric and maternal conditions were extreme maternal morbidity and the least incident maternal mortality. The cumulative incidence was 0.000107 (95\% Cl: 0.000088 to 0.000127$)$. The details of the accumulated incidences by affiliation scheme are presented in Table 3 and their graphic representation in the forest plot Additional file 2- Illustration 8.

From the studies that described the frequency distribution of non-communicable diseases according to the affiliation scheme, the ratio of cases of extreme maternal morbidity for CS is 2.6 to 1 compared to the SS of the SIVIGILA data, and for maternal mortality and morbidity and mortality combined, the number of cases is lower in CS compared to SS $(40,46,48,157,217,224,242,293)$. Details are presented in table 5.

\section{Common conditions in early childhood}

The early childhood disorder with the highest incidence in CS was neonatal death and congenital defects had the lowest incidence. The pooled incidence result of common conditions in early childhood for this scheme was 0.048309 ( $95 \% \mathrm{Cl} 0.047478$ to 0.049141$)$. These data came mostly from INS reports and information was identified between 2009 and 2021. The details of the cumulative incidences by affiliation scheme are presented in Table 3 and their graphic representation in the forest plot Additional file 2- Illustration 9. 
Infant mortality presented a ratio of 2.4 for CS with respect to SS $(39,45,69,217)$, as identified in Additional file 2 -Table 4.

\section{Other diseases}

In CS, the cumulative incidence for this category was 0.000309 (95\% Cl: 0.000284 to 0.000333 ), with intrafamily and gender violence being the most incident disease and alterations due to external causes secondary to cosmetic procedures the least incident. The source of information was the mandatory reports of the INS SIVIGILA. The details of the cumulative incidences by affiliation scheme are presented in Table 3 and their graphic representation in the forest plot Additional file 2- Illustration 10.

\section{Comparison of disease burden between SS and CS}

The relative risk for non-communicable and communicable diseases as categories was lower in the SS than in the CS (RR: 0.37 and 0.72 respectively, $\mathrm{p}$-value $<0.05)$, however, for the other three categories, Although differences are found, these represent a greater risk for the population affiliated with the SS, finding, for example, that the risk of presenting obstetric and maternal conditions in the SS versus the CS is RR 1.55 , for frequent conditions of early childhood RR 1.28 and from other conditions RR 1.28 , with p-value $<0.05$ in all cases. Details are presented in Table 3.

\section{Non-comparative SS disease burden}

The documents that presented information only for the SS between the years 1993 to 2021 were 42 . Information related to pathologies such as infant malnutrition, pertussis, accidental tetanus, ophidian accident, leishmaniasis, gestational syphilis, maternal mortality, malaria, cancer (tumors solid and hematoncological), leptospirosis, leprosy, yellow fever, acute chagas disease, Zika, congenital defects, dengue, puerperal endometritis, infections associated with medical-surgical procedures, chronic diseases, sexually transmitted diseases, maternal complications, HIV, intestinal parasites, death perinatal and migraine.

According to the type of document, academic theses, reports of mandatory notification events, infographics, technical reports of outbreak studies, scientific articles and poster summaries were identified, coming from both public and private entities.

\section{Non-communicable diseases}

The information presented contains data between 1998 and 2021. Regarding the 3 reports presented by the INS corresponding to the pathology of cancer in children under 18 years of age, acute, moderate and severe malnutrition in children under five years of age for 2021 and 2020 , a $33 \%, 66 \%$ and $64 \%$ of cases occurred in the RS, respectively.Table 7.

Agudelo et al. (216) carried out an ecological study published as a academic thesis whose objective was to establish the behavior of mortality due to child malnutrition in children under 5 years of age in Colombia and its relationship with some social determinants of health, the data source came of the National Administrative Department of Statistics information bases. A total of 12,165 deaths were found and the results show that the correlation between SR and mortality due to malnutrition in children under 5 years of age, children under 1 year of age, and children between 1 and 4 years of age was 0.2057 (Spearman Rho ) p-value: 0.0000 , Rho 0.1933 p-value: $0.0000,0.2147$ (Speaman Rho) p-value: 0.0000 respectively.

Afanador-Echeverría et al. (50) presented an abstract in which the current epidemiological situation of migraine in Colombia was analyzed, estimating the general prevalence by geographic areas based on the data obtained from the Individual records of provision of services (IRPS). This study included a total of 429,816 participants during the years $2014-2018$, of which $68.8 \%$ of the diagnoses were in SS patients and $26.8 \%$ in CS patients.

On the other hand, Parra-Lara et al. (17) present a poster summary, whose main objective was to analyze the 5-year global survival of patients with gastric cancer in relation to the health scheme and the place of residence (rural or urban) in a specialized health center in the city of Cali. A total of 500 cases of gastric cancer were included, the main outcome (5-year overall survival) was different for patients affiliated to the SS $14.96 \%$ (95\% $\mathrm{Cl}$ : 4.61 to 30.95 ) versus $26.69 \%$ (95\% Cl: 19.9 to 33.94 ) of the CS patients (p-value: 0.0089$)$.

Castañeda et al. (222) carried out an academic thesis (retrospective cohort) that aimed to describe the burden of disease due to acute pediatric leukemias (APL) and identify its association with inequalities in terms of affiliation scheme and department of origin in Colombia during the period 2011-2012. The data sources used were the IRPS and vital statistics registered in the DANE of the participating institution. A total of 636 cases of children who died from APL were included and the prevalence of mortality from APL for SS was 9.43 and for CS it was 9.39 and the mortality rate per 100,000 inhabitants was 1.49 for SS. CS and 2.19 for SS.

Table 7. Description of studies with information on noncommunicable diseases from the SS, 2020-2021

\begin{tabular}{|lllllllll} 
Author, year & Type of document & Nature & Source & Health condition & Total & Cases SS & $\%$ \\
\hline INS, 2021 & infographic & Public & INS & Cancer in children under 18 years of age & 342 & 113 & 33,04 \\
\hline INS, 2021 & infographic & Public & INS & Malnutrition in children under five years of age & 8.643 & 5.789 & 66,97 \\
\hline INS, 2020 & Disease report & Public & INS & Malnutrition in children under five years of age & 6.988 & 4.515 & 64,61
\end{tabular}

INS: National Institute of Health, SS: Subsidize scheme

\section{Communicable diseases}


The information related to the SS was found in 37 documents, of which 30 came from the INS. These data report information between 2010 and 2021. Neonatal trachoma and tetanus accounted for all cases in the SS for 2019 and 2020, and neonatal tetanus for 2020 and 2021 . The information is detailed in additional file 3 , table 2 .

Cardona et al. 2014 (62), published a study on the prevalence of a positive cytology result for bacterial vaginosis, candidiasis and trichomoniasis during 2010 and 2012 in the city of Medellín. The study aimed to determine the prevalence of positive cytology results for bacterial vaginosis, candidiasis, and vaginal trichomoniasis. The main source of information was obtained from the cervical cancer detection and prevention program at the Hospital Metrosalud de Medellín in the SS. 206,035 records from the program databases were included, finding that the prevalence of bacterial vaginosis was $18 \%$, candidiasis $4.7 \%$, and trichomoniasis $0.8 \%$. On the other hand, Cardona et al. (60), in another study carried out in the city of Medellín between 2010 and 2011 , which sought to determine the prevalence of bacterial vaginosis in women from Medellín and whose source of information came from 50 health centers and hospital units included; It was found that only $41.48 \%$ of the women in the SS was users of family planning methods.

Rivillas et al. (54) in an ecological study whose objective was to measure socioeconomic inequality and inequality related to health financing in maternal mortality in Colombia, as well as to identify the potential epicenters of this inequality, indicated that maternal mortality for the indicator of absolute inequity for expenses in health was, in the SS in the year 2012 of $-10,542,2013$ of $-13,979$ and in the year 2014 of $-64,781$; While for the CS it was $-32,895$ in 2012 , $-23,241$ in 2013 and $-17,283$ in 2014 . This study concluded that there is a high inequality in maternal mortality between the regions and, in particular, in the SS.

Arrivillaga et al. (52) published a cross-sectional study that aimed to evaluate and analyze the association between adherence to treatment and the social position of women living with HIV. This study was carried out during 2006 and 2008 and was part of the project "Social perspective of adherence to treatment in Colombian women with HIV / acquired immunodeficiency syndrome (AIDS). A total of 269 women with HIV / AIDS were included in five cities of the country (Cali, Bogotá, Villavicencio, Pasto and Medellín). The main results showed that the probability of remaining adhered to treatment is three times lower when the patient is affiliated with the SS (OR $=3,478,95 \% \mathrm{Cl}: 1,957$ to 6,181$)$ compared to the $\mathrm{CS}$.

Pinzón et al. (38), on the other hand, carried out a study with the objective of establishing the relationship between intestinal parasitism in children under 6 years of age and living in environmentally protected areas, without aqueduct service, in El Codito -Bogotá, Colombia. This cross-sectional study included 144 children between 4 and 70 months of age and demonstrated that, compared with affiliation to the CS, the children affiliated to the SS presented differences in the risk of intestinal parasitic diseases, however, they were not statistically significant ( $\mathrm{OR}=1.49,95 \% \mathrm{Cl} 0.48$ to 4.68$)$.

According to Cortez et al. (24), who published a retrospective descriptive study that characterized perinatal mortality in Manizales between 2009 and 2012 , according to sociodemographic, clinical, health care variables, affiliation scheme and their relationships, showed that the perinatal mortality rate during the years mentioned was 8.9 per 1,000 live births in the CS, and 9.8 per 1,000 live births in the SS; while the frequency of perinatal mortality was similar in both affiliation scheme (CS $=50.9 \%$ and $S S=49.1 \%)$.

Borrero et al. (43), published a study that aimed to evaluate the effect of decentralization in the context of the Colombian health system SGSSS, on the incidence of malaria in Colombian municipalities. This was an ecological study that performed a univariate analysis between the affiliation scheme and the malaria incidence rate between the years 1998-2004. The primary source of information was the departmental and municipal health secretaries. A total of 145 cases met the inclusion criteria. In the bivariate analysis between the type of affiliation and the ratio of malaria incidence rates in the municipalities, it was shown that the proportion of the municipal population belonging to the SC was 0.27 ( $95 \% \mathrm{Cl} 0.11$ to 0.64 ), and the proportion of the municipal population belonging to the SS was $4.2395 \% \mathrm{Cl}(1.98$ to 9.00$)$. Which means that the higher the proportion of the population affiliated with the subsidized regime, the higher the incidence rates of malaria in the municipalities.

\section{Maternal and obstetric conditions}

Six reports from the INS are listed in table 8 and show that $56.7 \%$ of the cases of gestational syphilis for the year 2021 were presented in the SS, likewise, for the year 2020 there was $54.3 \%$ of the same pathology in the SS population.

Diaz et al. (246), carried out an ambispective cohort study whose main objective was to determine the factors associated with complications during the third trimester of pregnancy, childbirth and the puerperium of maternal women belonging to the SS treated in a second-level institution of complexity in Medellín during the year 2012. The cohort had a total of 506 maternal included and among the main maternal complications prior to the current pregnancy of the included participants, the prevalence of abortion was $24.5 \%$, pre-eclampsia $8.2 \%$, premature delivery $4.3 \%$ and intrauterine growth retardation $0.9 \%$.

Amaya et al. (72), in their cross-sectional study, had as objective to evaluate factors that were associated with 28 cases of maternal mortality that occurred during 2008 in women affiliated to an HPE of the SS, calculating the maternal mortality ratio of 28 deaths per 29,944 live births .

Acevedo et al. (230), carried out a study published as an academic thesis that aimed to identify contextual and individual factors related to maternal health, during the years 2011 to 2015 in Vichada. The pregnant women affiliated to the administrative entities of benefit plans (AEBP) of the SS had a maternal mortality ratio of 715.26 deaths per 100,000 live births and the risk of dying of the pregnant women affiliated to this scheme was 5 higher $(O R=5.48$; $95 \%$ Cl: 0.8812 to 226.58 ) with respect to uninsured pregnant women, although there were no statistically significant differences. There were no cases in women affiliated to the AEBP of the CS or to the exception scheme.

Table 8. Description of articles with information from the SS, 2018-2021 


\begin{tabular}{llllllll} 
Author, year & Type of document & Nature & Source & Health condition & Total & Cases SS & \% \\
\hline INS, 2021 & infographic & Public & INS & Gestational syphilis & 6.391 & 3624 & 56,7 \\
\hline INS, 2018 & Disease report & Public & INS & Maternal mortalitty & 523 & Maternal mortality ratio 44,0 cases per 100.000 births \\
\hline INS, 2021 & Disease report & Public & INS & Puerperal endometritis & 704 & 286 & 40,6 \\
\hline INS, 2020 & Disease report & Public & INS & Puerperal endometritis & 319 & 141 & 44,2 \\
\hline INS, 2020 & Disease report & Public & INS & Puerperal endometritis & 704 & 286 & 40,6 \\
\hline INS, 2020 & Disease report & Public & INS & Gestational syphilis & 5.643 & 3064 & 54,3
\end{tabular}

INS: National Institute of Health, SS: Subsidize scheme

\section{Behavior in the use of healthcare services according to affiliate schemes in Colombia}

Use of health services in affiliation schemes in Colombia described from studies and reports that reported the distribution of use differently. The number of references included was 21, which reported information between 2009-2021. Details are presented in additional file 3, Table 3.

In this table, the rates of higher frequency of use of health services in the regimens were established, it is found that the use of radiotherapy, chemotherapy and radiotherapy, mastectomy, among others, is greater when exposed to SS compared to CS. additional file 3, Table 3.

The additional file 3, Table 4. Show in greater detail a study developed by the MHSP valuating the quality of care provided in Colombia in 2014 , the data showed that there is a greater risk of consumption of services, specifically for drug delivery services, hospitalization, requesting procedures to the HPE in person and not requesting procedures to the HPE when exposed to SS than when exposed to CS.

For the use of service in relation with health promotion, prevention and surgery there were no statistically significant differences between the SS and CS, and it is notable how the risk of consuming resources for general medicine services, laboratory tests, specialized medicine, emergencies, dentistry, radiography and images, priority appointments, therapies, requesting medical appointments via telephone or internet is lower when you are exposed to SS compared to CS.

Zuñiga et al. (253) published an analytical observational study, conducted during 2018, which aimed to analyze inequality in prenatal care live births in Colombia in 2018 by type of health insurance. The database of the registry of live births was analyzed, with a total of 459,238 records and within the results found: a mean number of prenatal controls for SS of 6.04 ( $95 \% \mathrm{Cl}: 6.03$ to 6.05 ) and for CS 7.40 (95\% Cl: 7.39 to 7.41 ). Likewise, live births to mothers affiliated with the SS were 3.5 times more likely (OR=3.545; $95 \% \mathrm{Cl}: 3.479$ to 3.611$)$ to have four or fewer prenatal check-ups compared to the CS:(OR=0.288; $95 \%$ Cl: 0.283 to 0.294$)$.

Additional file 3, Table 5, on the other hand, shows the distribution of health services according to the affiliation scheme of the study population. Information was obtained from 3 studies, carried out between 2009 and 2019 where services such as delivery care, time of health care attention were evaluated, with a ratio between 5.41 to 1 cases in the SS with respect to the CS.

\section{Quality assessment}

Studies were assessed according to the study design. 29 articles were classified as cross-sectional studies. Eight articles $(18,20,24,33,39,40,43,54)$ were considered with high concerns due the risk of bias mainly because of the lack of information regarding the subject's settings and the sample size. Three $(23,45,47)$ cohort studies were flagged as high concerns due the risk of bias due unclear information about exposures measures whether control or exposed groups. One (49) study was evaluated with a case series tool and this was considered as low concerns of risk of bias. For more information see additional file 4 .

\section{Discussion}

The objective of this study was to identify the epidemiological profile of the population affiliated with the SS in Colombia, to establish whether there are differences compared to the CS in terms of: incident diseases, prevalent diseases, and use of health services, and to estimate the magnitude of the differences from statistical analyzes of the data retrieved in a systematic review of data published in the literature and other sources of information. As a main result, it was determined that there are significant differences in the use of health services and incident and prevalent diseases between the population affiliated with the SS and the CS in Colombia. The direction of these differences points to the existence of a greater burden of disease in terms of morbidity and mortality for SS in the categories of obstetric and maternal conditions, which includes maternal morbidity, extreme maternal morbidity, maternal and perinatal mortality (RR 1.5), the category of frequent childhood conditions with a RR of 1.27 and finally, the category of other diseases or conditions, among which injuries due to violent causes stand out (RR 1.28).

These findings can be explained due to the greater vulnerability of the population in these categories, the pregnant population, for example, is definitely more vulnerable to barriers to access and provision of health services, these barriers translate into absent or incomplete prenatal controls, This increases the risk of detection, management and prevention of complications typical of this physiological state with consequences that can be catastrophic for the mother and the product of pregnancy.

Likewise, it is not unknown that the population affiliated with the SS presents vulnerability characteristics secondary to precarious access to essential public services, the quality of food, transportation and restricted movement, either due to its location in dispersed areas or due to difficult access when found within

Page $12 / 25$ 
population centers. These characteristics, added to the existing biological vulnerability in children under five years of age, cause the risk of morbidity and mortality to be greater in this age group, malnutrition, mortality associated with malnutrition, congenital malformations, postnatal nutritional deficiencies, among others, are problems that they occur more frequently in the population affiliated with the subsidized scheme and are mediated beyond the biological substrate, by social determinants of health.

Also, the different forms of violence that are monitored in the national information systems were predominant in the population affiliated to the SS, this gender violence, intrafamily violence, as well as sexual abuse, intoxications and consumption accidents, can be understood as a manifestation of unsatisfied basic needs, gender inequalities, lack of purchasing power, unemployment, inequality in income, level of education (303) and sociocultural patterns and historical violence such as the armed conflict, which demarcate differences in social positions (304).

Other important findings were the significant differences in the incidence of communicable and non-communicable diseases between those affiliated with the SS and CS, with a higher risk of incidence in the population affiliated with the CS. This finding, which is contrary to what is expected given the marked additional risk that has been described for the occurrence of these diseases in a population with a higher degree of vulnerability (55,305,306), can be explained for two reasons. The first one related to the quality of health information systems and registries at the national level, which constituted a primary source of information for this analysis. It is recognized that the information for the SS and the characterization of the use of health system resources, as well as the burden of disease in its affiliates is deficient, not representative and in most cases not available, which may mean in this case an underreporting of the number of cases and the systematic deviation of these incidents towards an underestimation. Also, structural, and intermediate problems of the health system, related to the location of residence of the population affiliated to the SS, deficiencies in transportation, limitations in mobility due to civil security problems, and the location and organization of service-providing institutions. They constitute barriers that limit the access of this population to care, so that care is not received in the institutions and consequently they are not recorded in the information systems. This problem also generates a bias in incidents with a tendency to underestimate.

The characterization of the prevalence of communicable and non-communicable diseases in the country according to the scheme comes from more representative studies, although fragmented by regions or municipalities in many cases. The distribution of cases in the identified morbid cohorts shows a ratio greater than 1 in the cases of patients affiliated to the SS versus CS who have chronic diseases such as cardiovascular disease and arterial hypertension (ratio 1.3: 1), lesions in skin, mortality due to nutritional deficiencies, malnutrition that represent cases of SS with respect to CS in a ratio of approximately $2: 1$ or in the case of epilepsy or other chronic diseases that represent cases of SS with respect to CS in a ratio of > 3: 1 .

This same pattern was observed in communicable diseases such as the occurrence of acute Chagas disease, tuberculosis, sexually transmitted diseases, HIV, intestinal parasitic infection ( $>1: 1)$, congenital and gestational syphilis, chronic Chagas disease ( $>4: 1)$. The relative risk of the occurrence of communicable diseases such as leprosy, congenital syphilis, whooping cough, Zika, Leishmaniasis, equine encephalitis, malaria, trachoma, and neonatal tetanus is also higher in the population affiliated to the SS than in the CS.

It is especially noteworthy in this study that in the morbid cohorts with cancer in which there is a report in national databases, the largest number of affiliates are found in the CS. Another important finding in this study is related to the presentation of the disease in the population affiliated to the SS, its severity, and the differential behavior of the clinical course of some of them. In one of the studies included in this analysis, it was evident at least for the population in Cali how screening services for malignant breast disease are provided in a 0.5: 1 ratio in women from the SS compared to those from the CS , and in women who were diagnosed with breast cancer, there was a 2.8 times higher risk of requiring mastectomy in women with this condition affiliated with the SS than in those with the CS, which may be a proxy for the severity of the disease at the time of diagnosis.

The differences found in the course of the disease are also relevant and induce a reflection on the process of care within the IPS for the population affiliated with one or another scheme. For example, in Bogotá, by 2020, it was found that the risk of having a patient with rheumatoid arthritis with high disease activity at the beginning of the two-year follow-up was lower in SS compared to CS (OR 0.1), however, upon completing the follow-up time, the risk of presenting high disease activity was higher in SS compared to CS (OR 1.8), reversing the trend observed at the beginning of follow-up in patients. Also in delivery care, cesarean sections were more frequent in CS than in SS. These findings denote a possible differential approach and other factors that are mediating the differential health outcomes in the population that demands and accesses health services in each of these schemes.

Other greater risks that in turn determine a greater burden of disease in SS patients are related to a greater possibility of having failed tuberculosis treatments (OR 1.3) or fewer complete treatments (OR 0.4), a greater possibility of having epilepsy refractory (OR 4.6), abandonment of breastfeeding (OR 1.3), fewer promotional and preventive activities such as vaginal cytology (OR 0.8), complete vaccination schedules (OR 0.4 ) or higher risk of having complete but late vaccination schedules (OR 2.4).

Regarding the use of services offered in the health system, the trend was also evident in terms of relative frequencies, towards less use of health services in the SS compared to the CS. Such is the case of general medicine services, medication delivery, laboratory tests, specialized medicine, emergency service care, dentistry, radiology and imaging, priority appointment care and therapies. However, the risk of requiring hospitalization in the population affiliated with the SS is greater than that affiliated with the CS (OR 1.65). The use of prevention and promotion health services (P\&P) and the performance of surgical procedures does not imply an additional risk in any of the schemes (OR 1.0).

This trend in the differential use of health services, with a lower frequency of use and care in the SS, is understandable to the extent that the population affiliated with this scheme has greater barriers to access health services located beyond of the provision of services and availability of health technologies. Among them, the characteristics of informality in the work activity that generates a competition between seeking care and obtaining income that guarantees subsistence. The lower availability of tools that facilitate the request for health care services and their continuity, such as the telephone or internet service or the lack of knowledge and appropriate use of this resource, a fact that again impacts the need of transfers in person to the institutions or service points

Page $13 / 25$ 
arranged for it. This confronts them with access barriers generated by problems due to lack of transportation, mobility, geographical areas and barriers, and the availability of economic resources for it. This last phenomenon was also evident in this study, finding that the request for health services in person is 3.6 times higher in the SS, so it also occurs with procedures in person OR 2.1 and in the worst of cases the non-request for procedures or services 1.7 times more frequent in the population affiliated with the SS.

This study, which sought to identify the differences in the incidence, prevalence of diseases and use of health services between the affiliation scheme (subsidized and contributory) in Colombia, is the first of this nature, which integrates information available in the literature and sources from of administrative bases and epidemiological surveillance in Colombia, combining advanced statistical methods for the estimation of combined measures of incidents and analysis of prevalences in each scheme. Additionally, formal statistical tests were carried out, which made it possible to find and quantify the magnitude of the existing differences in the occurrence of disease and use of health services in Colombia for these two health affiliation schemes.

The sources of information in turn suppose important limitations, among them, the categories of diseases generated a priori could only be fed with information on health conditions and diseases with information available in the literature or in the surveillance information bases, however, do not constitute all of the diseases that are part of these categories and in some cases, they are not the most frequent presentation.

\section{Conclusion}

This study allowed to conclude that there are differences in the incidence, prevalence and use of health services between health affiliation scheme (SS and CS) in Colombia. For the categories configured in the framework of this study as communicable and non-communicable diseases, the data showed a greater risk of becoming ill from this cause in the population affiliated to the CS, however, the certainty in this estimate is very low given the potential biases of information, selection and measurement detected in the information sources, which even allows predicting an underestimation of the incidents and prevalences of the conditions reported in the SS. For the categories of obstetric and maternal conditions, frequent conditions in early childhood and other diseases, the risk of occurrence was higher in those affiliated to the SS than in the CS. The use of health services is also different by scheme, finding less demand, access or provision in health services for general consultation, dentistry, drug delivery, emergency consultation, among others, in the SS, probably mediated by social determinants of health, other than the availability of health technologies. However, the risk of requiring hospitalization is greater in those affiliated to the SS.

These results not only allow quantifying and quantitatively demonstrating the differences that are presumed in the configuration of health in the populations belonging to the SS and CS in Colombia but can also guide decision-making regarding the aspects necessary for the actuarial estimation of values to be recognized by people according to the health insurer's scheme. It is necessary that aspects such as the social characteristics of the population are taken into account in the planning, organization and management of health risk, considering that they are determinants of the burden of disease and health results, as well as the configuration of uses services available, as well as barriers that impact the entire care process. There are many limitations in the recovered evidence, so it is necessary to promote studies that seek not only to overcome these limitations and reduce the risk of bias from the design, but also to achieve a greater degree of representativeness at the national level.

\section{Abbreviations}

Acquired immunodeficiency syndrome: AIDS

Acute pediatric leukemias: APL

Administrative entities of benefit plans: AEBP

Beneficiary Selection System: BSS

Capitation Payment Unit: CPU

Confidence interval: $\mathrm{Cl}$

Contributory scheme: CS

General System of Social Security in Health: SGSSS

Health Benefit Plan: HBP

Health Promoting Entities: HPE

Health Service Provider Institutions: HSPI

human immunodeficiency virus: HIV

Individual Service Provision Registry: IRPS

Interagency Coordination Platform for Refugees and Migrants from Venezuela: R4V

Ministry of Health and Social Protection: MHSP

Page 14/25 
National Administrative Department of Statistics: DANE

National Institute of Health: INS

Odds ratio: $\mathrm{OR}$

Promotion health services: P\&P

Public Health Surveillance System: SIVIGILA

Subsidized scheme: SS

Systematic review of literature: SRL

Tuberculosis: TB

Unique Affiliate Database: UAD

\section{Declarations}

\section{Authors' contributions}

LMM, KEO defined the scope of the research subject and developed the search strategy. LMM and KEO undertook the search, reviewed the literature, and summarized the search findings. LMM and KEO drafted the manuscript. LMM, KEO, OE, and LM, provided substantial input in the design stages of the review, critically reviewed the manuscript, and helped shape the final version of the manuscript. All authors approved the final manuscript.

\section{Acknowledgements}

Not applicable

\section{Funding}

This study if funded by Ministry of Finance and Public Credit of Colombia

\section{Availability of data and materials}

The data and materials will be available if are required

\section{Ethics approval and consent to participate}

Not applicable

\section{Consent for publication}

All authors are agreeing with the content of this manuscript

\section{Competing interests}

The authors declare that they have no competing interests.

\section{References}

1. Ministerio de Salud y Protección Social. Aseguramiento al Sistema General de Seguridad Social. Minsalud [Internet]. 2017;63. Available from: https://www.minsalud.gov.co/sites/rid/Lists/BibliotecaDigital/RIDE/VP/DOA/RL/cartillas-de-aseguramiento-al-sistema-general-de-seguridad-social-ensalud.pdf

2. Ministerio de Salud y Protección Social. Resolucion 2503 de 2020. Vol. 93, Acta Medica Scandinavica. 2009. p. 22-70.

3. Ministerio de Salud y Protección Social. Unidad de pago por capitación del regimen subsidiado [Internet]. 2021 [cited 2021 Sep 8]. p. 1. Available from: https://www.minsalud.gov.co/salud/Paginas/UPC_S.aspx

4. Nieto López E, Londoño Fernández J. Factores socioeconómicos y aseguramiento en salud en el área urbana de Colombia. Fac Nac Salud Pública El Escen para la salud pública desde la Cienc. 2001;19(1):2.

5. Ministerio de Salud y Protección Social. Resolucion 2503 del 2020. Acta Med Scand. 2009;93(S85):22-70.

6. Ministerio de Salud y Protección Social. La equidad en Salud para Colombia. Brechas internacionales y territoriales. 2015.

7. Mejía-Mejía A, Sánchez-Gandur AF, Tamayo-Ramírez JC. Equidad en el Acceso a Servicios de Salud en Antioquia, Colombia TT - Equity in access to health-services in Antioquia, Colombia. Rev salud pública [Internet]. 2007;9(1):26-38. Available from: http://www.scielosp.org/scielo.php?

script=sci_arttext\&amp 
8. Liliana Hilarión-Gaitán, Diana Díaz-Jiménez, Karol Cotes-Cantillo CC-O. Vista de Desigualdades en salud según régimen de afiliación y eventos notificados al Sistema de Vigilancia (Sivigila) en Colombia, 2015 [Internet]. Biomedica: revista del Instituto Nacional de Salud. 2019 [cited 2021 Sep 12]. Available from: https://revistabiomedica.org/index.php/biomedica/article/view/4453/4274

9. Garritty C, Gartlehner G, Kamel C, King VJ, Nussbaumer-Streit B, Stevens A, et al. Interim guidance from the cochrane rapid reviews methods group. Cochrane Rapid Rev [Internet]. 2020;2020(March):1-2. Available from:

https://methods.cochrane.org/rapidreviews/sites/methods.cochrane.org.rapidreviews/files/public/uploads/cochrane_rr_-_guidance-23mar2020-final.pdf

10. Moher D, Shamseer L, Clarke M, Ghersi D, Liberatî A, Petticrew M, et al. Preferred reporting items for systematic review and meta-analysis protocols (PRISMA-P) 2015 statement. 2015 [cited 2021 Sep 16]; Available from: http://www.crd.york.ac.uk/prospero

11. Adelaide. TU of. critical-appraisal-tools - Critical Appraisal Tools | Joanna Briggs Institute [Internet]. The University of Adelaide. [cited 2022 Jan 3]. Available from: https://jbi.global/critical-appraisal-tools

12. ADRES. Base de Datos Unica de Afiliacos - BDUA [Internet]. ADRES. 2021 [cited 2021 Dec 5]. Available from: https://www.adres.gov.co/eps/procesos/bdua

13. Wang N. How to Conduct a Meta-Analysis of Proportions in R: A Comprehensive Tutorial. John Jay Coll Crim Justice,. 2016 ;(June):1-63.

14. Nyaga VN, Arbyn M, Aerts M. Metaprop: A Stata command to perform meta-analysis of binomial data. Arch Public Heal. 2014;72(1):1-10.

15. Lipsey M. Practical meta-analysis. Thousand Oaks, Calif.: Sage Publications;; 2001. 247 p.

16. StataCorp. Stata: Software for Statistics and Data Science I Stata [Internet]. 2021 [cited 2021 Dec 5]. Available from: https://www.stata.com/

17. Parra-Lara L, Falla-Martinez J, Bravo J, Zambrano A, Bravo L. Health disparities and gastric cancer survival in Cali, Colombia: A hospital-based study. Ann Oncol [Internet]. 2019;30(Supplement 4). Available from: https://doi.org/10.1093/annonc/mdz155.340

18. Mejía-Mejía A, Sánchez-Gandur AF, Tamayo-Ramírez JC. Equidad en el acceso a servicios de salud en Antioquia, Colombia. Rev Salud Publica. 2007;9(1):26-38.

19. Lopera MM, Lemos Y. Factores socioeconómicos y clínicos asociados con infecciones oportunistas en pacientes con HIV afiliados al sistema de salud. Biomédica. 2019;39(1):186-204.

20. Gómez-De la Rosa F, Marrugo-Arnedo CA, Florez-Tanus Á, López-Pájaro K, Mazenett-Granados E, Orozco-Africano J, et al. Impacto económico y sanitario del control prenatal en embarazadas afiliadas al régimen subsidiado en Colombia durante 2014. Salud Publica Mex. 2017;59(2):176-82.

21. de Vries E, Uribe C, Pardo C, Lemmens V, Van de Poel E, Forman D. Gastric cancer survival and affiliation to health insurance in a middle-income setting. Cancer Epidemiol [Internet]. 2015;39(1):91-6. Available from: http://dx.doi.org/10.1016/j.canep.2014.10.012

22. Cruz LF, Epidemiol M, Girón LN, Enf L, Velásquez R, García LM, et al. Coberturas de vacunación en el Valle del Cauca, 2002. Colomb medica (Cali, Colomb. 2003;34:17-23.

23. Barahona-Correa JE, Flórez-Suárez J, Coral-Alvarado P, Méndez-Patarroyo P, Quintana-López G. Does healthcare regime affiliation influence the clinical outcomes of patients with rheumatoid arthritis? Clin Rheumatol. 2021;40(3):877-86.

24. Bernal Cortés DP, Cardona Rivas D. Caracterización de la mortalidad perinatal en Manizales, Colombia 2009-2012. Hacia promoc salud. 2014;19(2):2009-12.

25. Díaz-Grajales C, Zapata-Bermúdez Y, Aristizábal-Grisales JC. Acceso a los servicios preventivos en los regímenes contributivo y subsidiado de salud en un barrio estrato dos de la ciudad de Cali. Rev Gerenc y Polit Salud. 2011;10(21):153-75.

26. Gómez-Mercado CA, Segura-Cardona AM, Pájaro-Cantillo DE, Mesa-Largo M. Incidencia y determinantes demográficos de la leucemia linfoide aguda en pacientes con cáncer pediátrico, Antioquia. Univ y Salud. 2020;22(2):112-9.

27. Pinilla A, Cano N, Granados C, Paez-Canro C, Eslava-Schmalbach J. Inequalities in prescription of hydrochlorothiazide for diabetic hypertensive patients in Colombia. Rev Salud Publica [Internet]. 2011;13(1):27-40. Available from: http://www.scielosp.org/pdf/rsap/v13n1/v13n1a03.pdf

28. Garcés-Palacio IC, Altarac M, Kirby R, McClure LA, Mulvihill B, Scarinci IC. Contribution of health care coverage in cervical cancer screening follow-up: Findings from a cross-sectional study in colombia. Int J Gynecol Cancer. 2010;20(7):1232-9.

29. Martínez-Pérez DC, Gómez-Wolff LR, Ossa-Gómez CA, Hernández-Herrera GN, Rivas-Bedoya Y, García-García HI. Association between delayed diagnosis and breast cancer in advanced clinical stage at the time of consultation in four oncology centers in Medellin-Colombia, 2017. Cross-sectional study. Rev Colomb Obstet Ginecol. 2020;71(2):9-24.

30. Egurrola-Pedraza JA, Gómez-Wolff LR, Ossa-Gómez CA, Sánchez-Jiménez V, Herazo-Maya F, García-García HI. Survival difference due to types of health coverage in breast cancer patients treated at a specialized cancer center in Medellín, Colombia. Cad Saude Publica. 2018;34(12).

31. Yepes FJ, Gómez JG, Zuleta JJ, Londoño JL, Acosta-Reyes JL, Sánchez-Gómez LH, et al. Healthcare and maternal morbidity and mortality: a hospitalbased case-control study in two regions of Colombia (Bogotá and Antioquia), 2009-2011. Cad Saude Publica. 2016;32(11):e00080215.

32. Zabaleta A, Llerena C. Serie de casos: tuberculosis extremadamente resistente a drogas en Colombia, 2006-2016. Biomédica. 2019;39(4):707-14.

33. Osorio J. Prevalencia de caries e índice COP en población escolar de 12 años del municipio de Copacabana 2013-2014. Estomatologia. 2015;23(1):7-14.

34. Ortiz C, Rúa-Uribe GL, Rojas CA. Conocimientos, prácticas y aspectos entomológicos del dengue en Medellín, Colombia: un estudio comparativo entre barrios con alta y baja incidencia. Biomédica. 2018;38:106-16.

35. Houweling TAJ, Arroyave I, Burdorf A, Avendano M. Health insurance coverage, neonatal mortality and caesarean section deliveries: An analysis of vital registration data in Colombia. J Epidemiol Community Health. 2017;71(5):505-12.

36. Rubio-Mendoza ML. Equidad en el Acceso a los Servicios de Salud y Equidad en la Financiación de la Atención en Bogotá. Rev Salud Pública. 2008;10(1):29-43. 
37. Rocha M, Mendez Y, Giraldo M. Evaluation of Emotional, Social and Access Needs of Patients Diagnosed With Chronic Myeloid Leukemia in Colombia. Value Heal Reg Issues [Internet]. 2019;19(October):S24. Available from: https://doi.org/10.1016/j.vhri.2019.08.125

38. Pinzón-Rondón AM, Gaona MA, Bouwmans M, Chávarro LC, Chafloque J, Zuluaga C, et al. Acceso a agua potable, protección ambiental y parasitismo intestinal infantil en El Codito. Bogotá, Colombia. Rev Salud Pública. 2019;21(1):42-8.

39. Cardona D, Garzón MO, Calle M, Agudelo MC, Segura Á. Tendencia de la mortalidad y la morbilidad por tos ferina en Colombia, 2002-2012. Biomedica. 2016;36(3):397-405.

40. Briceño-Ayala L L, Pinzón-Rondón ÁM ÁM, Zárate-Ardila CJ CJ. Acceso, seguridad e integralidad en registros de gestantes colombianas entre los años 2007 al 2009. Ciencias la Salud. 2015;13(3):355-67.

41. Salamanca MEC, Equidad. Equidad en la utilización de servicios de salud en el Sistema General de Seguridad Social en Salud en Colombia. 2011; (July):1-7.

42. Gutiérrez CC, Reyes-Ortiz C, Borda MG, Arciniegas A. El auto reporte de vacunación en los adultos mayores: Estudio SABE Bogotá, Colombia. Colomb Med. 2016;47(1):25-30.

43. Borrero E, Carrasquilla G, Alexander N. Decentralization and health system reform: what is their impact on malaria incidence in Colombian municipalities. Biomedica. 2012;32 Suppl 1(March):68-78.

44. Garcia-Subirats I, Vargas Lorenzo I, Mogollón-Pérez AS, De Paepe P, da Silva MRF, Unger JP, et al. Determinantes del uso de distintos niveles asistenciales en el Sistema General de Seguridad Social en Salud y Sistema Único de Salud en Colombia y Brasil. Gac Sanit. 2014;28(6):480-8.

45. Velásquez-De Charry LC, Carrasquilla G, Roca-Garavito S. Equidad en el acceso al tratamiento para el cáncer de mama en colombia. Salud Publica Mex. 2009;51(SUPPL.2).

46. Catalán Álvarez V. Factors of Accessibility Related To Perinatal Death. Rev Investig Programa Enfermería UDES [Internet]. 2010;1(1):26-34. Available from: http://www.scielo.org.co/pdf/cuid/v1n1/v1n1a05.pdf

47. de Charry LC, Carrasquilla G, Roca S. Equidad en la detección del cáncer de seno en Colombia. Rev Salud Publica. 2008;10(4):571-82.

48. Alvarez-Sierra SP. Demoras en mortalidad materna en el departamento de Santander 2012 a 2015. Rev Salud Pública. 2018;20(6):699-706.

49. Agudelo Loaiza RD, Medina Arredondo MC, Cardona Rivas D. Caracterización de la sífilis congénita y gestacional en Caldas, Colombia. Arch Med. 2016;16(2):326-34.

50. Afanador Echeverri GF, Ribero V. Current Situation of Migraine in Colombia: Analysis Based on the Health Services Information System (RIPS). Value Heal [Internet]. 2019;22(May):S286. Available from: https://doi.org/10.1016/j.jval.2019.04.1358

51. Ettenger A, Bärnighausen T, Castro A. Health insurance for the poor decreases access to HIV testing in antenatal care: Evidence of an unintended effect of health insurance reform in Colombia. Health Policy Plan. 2014;29(3):352-8.

52. Arrivillaga M. Social position, gener role, and treatment adherence among Colombian women living with HIV/AIDS: social determinants of health approach. Enhanc Read. 2009;1-10.

53. Benjumea Bedoya D, Arbeláez Montoya MP. Estudio y manejo clínico de menores que conviven con pacientes de tuberculosis pulmonar, Medellín 20102011. latreia. 2015;28(2):137-47.

54. Rivillas JC, Devia-Rodriguez R, Ingabire M-G. Measuring socioeconomic and health financing inequality in maternal mortality in Colombia: a mixed methods approach. Int J Equity Health. 2020 Jul;19(1):98.

55. Hilarión-Gaitán L, Díaz-Jiménez D, Cotes-Cantillo K, Castañeda-Orjuela C. Desigualdades en salud según régimen de afiliación y eventos notificados al Sistema de Vigilancia (Sivigila) en Colombia, 2015. Biomedica. 2019;39(4):737-47.

56. Paniagua-Saldarriaga LA, Pelissari DM, Rueda ZV. Factors Associated with Unsuccessful Outcomes of Tuberculosis Treatment in 125 Municipalities in Colombia 2014 to 2016. Am J Trop Med Hyg. 2021 Sep;

57. Hernández Bernal NE, Bulla AP, Mancilla López E, Peña Peña LV. Prevalencia de lesiones de piel asociadas a la dependencia física en geriátricos e instituciones de salud de Tunja. Gerokomos. 2021;32(1):51-6.

58. Díaz-Grajales C, Zapata-Bermúdez Y, Aristizábal-Grisales JC. Acceso y satisfacción con servicios curativos: Análisis de casos en afiliados al régimen contributivo y afiliados al régimen subsidiado en un barrio estrato 2 - Cali, Colombia. Rev Gerenc y Polit Salud. 2015;14(29):155-78.

59. Anaya Anichiarico A, Londoño Villaquiran F, Pérez Varela L, Ortiz Martinez R. Caracterización de las pacientes llevadas a cesárea según modelo de Robson y exploración de factores asociados en gestantes atendidas en el hospital Universitario San José de la ciudad de Popayán-Colombia. 1 de enero de 2016 a 30 de junio de 2016. Rev Chil Obstet Ginecol. 2017;82(5):491-503.

60. Ángel-Müller E, Rodríguez A, Núñez-Forero LM, Moyano LF, González P, Osorio E, et al. The prevalence of and factors associated with C. trachomatis, N. gonorrheae, T. vaginalis, C. albicans infection, syphilis, HIV and bacterial vaginosis in females suffering lower genital tract infection symptoms in three healthcare attention sites in Bogo. Rev Colomb Obstet Ginecol. 2012;63(1):14-24.

61. Antonio J, Arias C, Arredondo MV. Prevalencia de vaginosis bacteriana en usuarios de una institución prestadora de servicios de salud de Medellín Colombia. Investig Andin. 2015;17(30):1151-65.

62. Jaiberth Antonio Cardona-Arias, Daniela Herrera-Posada MV-A. Prevalencia de resultado positivo de la citología para vaginosis bacteriana, candidiasis y tricomoniasis en una Empresa Social del Estado de Medellín-Colombia, 2010-2012. Univ Antioquia. 2012;(1):46-50.

63. Lechuga EN, Martínez RP de las S. Uso de la citología vaginal en mujeres afiliadas al régimen subsidiado atendidas en la unidad hospitalaria la manga de barranquilla (Colombia), 2006. Salud Uninorte. 2008;24(2):191-204.

64. Liced Marcela Morán Garreta , Elisa María Pinzón Gómez , Víctor Hugo Muñoz Villa , Maria Cristina Lesmes Duque MCVG. Abuso sexual en mujeres de 10 a 13 años en el Valle de Cauca, Colombia. Arch Med. 2008;(April):2008.

Page $17 / 25$ 
65. Luis F, Jaramillo O. Mortalidad por cáncer en Colombia 2001. Rev CES Med. 2004;18(2):19-36.

66. Pastrán Alfonso O, Céspedes Nieves G, Ruiz Latriglia MF, Silva Preciado S. Caracterización de personas con discapacidad del municipio de Sopó, Cundinamarca, Colombia. Rev Colomb Rehabil. 2017;7(1):15.

67. Pereira FD, Sáenz I. Hemoglobinopatías en niños. Colomb Med. 1996;27:146-9.

68. Piñeros M, Sánchez R, Perry F, García OA, Ocampo R, Cendales R. Demoras en el diagnóstico y tratamiento de mujeres con cáncer de mama en Bogotá, Colombia. Salud Publica Mex. 2011;53(6):478-85.

69. EMSANAR E. Caracterización de pacientes afiliados a la Empresa Promotora de Salud del Régimen Subsidiado (EPS-S)“EMSSANAR." 2015;

70. Ruiz-Murcia FA, Fandiño-Losada A, Ramirez-Cheyne J, Isaza C, Saldarriaga W. Inequidades en el diagnóstico de anomalías congénitas mayores en recién nacidos en Cali, Colombia. Rev Chil Obstet Ginecol. 2014;79(6):481-8.

71. Yolanda I, Ávila C, Margarita K, Velasco A, Barón MM. Citología cervicovaginal. Hacia promoc salud. 2013;(2):123-34.

72. Bolaños ÁP, Cuevas AM, Díaz DI. Factores asociados con la mortalidad materna en las afiliadas a una EPS del régimen subsidiado, durante el año 2008. Cuad Latinoam Adm. 2010; $\mathrm{VI}(10): 103-18$.

73. Borda MG, David-Pardo DG, Ríos-Zuluaga JD, López-Zea Al, Forero-Borda LM, Gutiérrez S, et al. Relationship between prostate cancer screening, linkage to the health system and associated factors in older adults from Bogotá, Colombia: Secondary analysis of the SABE survey. Urol Colomb. 2018;27(1):35-41.

74. Cardona-Arango D, Segura-Cardona Á, Espinosa-López AM. Mortalidad de adultos mayores por deficiencias nutricionales en los Departamentos de Colombia. Rev Salud Publica. 2012;14(4):584-95.

75. Daza V, Jurado W, Duarte D, Gich I, Sierra-Torres CH, Delgado-Noguera M. Low birth weight: Exploring of some risk factors at the San José teaching hospital in Popayán, Colombia. Rev Colomb Obstet Ginecol. 2009;60(2):124-34.

76. María Angélica Echavez Sánchez, Romero JAB. Vigilancia epidemiológica de la sífilis gestacional y congénita en el departamento de córdoba, Colombia, 2012- 2016. Rev Salud Pública. 2019;

77. Farías-Curtidor LE, Mejía-Bernal CP, Osorio-Carmona GI, Pérez-Peña LJ, Preciado-Aponte C. Factores de riesgo para el desarrollo de Tuberculosis multidrogorresistente en Colombia, 2008 A 2011. Rev Salud Publica. 2016;18(6):845-57.

78. García Ramírez JA, Vélez Álvarez C. Social determinants of health and quality of life of the adult population of Manizales, Colombia. Rev Cuba Salud Publica. 2017;43(2):191-203.

79. Herrera Marcano T, Cachada A, Rocha-santos T, Duarte AC, Roongtanakiat N. Lesiones intraepiteliales de alto grado en la población subsidiada, contributiva y pobre no asegurada en el municipio de Villavicencio, Colombia. 2008. Univ del Rosario [Internet]. 2009; Available from: http://dx.doi.org/10.1016/B978-0-12-849873-6.00001-7\%0Ahttp://saber.ucv.ve/ojs/index.php/rev_venes/article/view/1112

80. Instituto Nacional de Salud (INS). Síndrome de rubeola congenita. Inst Nac Salud. 2020;

81. Instituto Nacional de salud INS. Tuberculosis. Inst Nac Salud. 2019;

82. Instituto Nacional de Salud (INS). Parotiditis. Inst Nac Salud. 2019;

83. Martinez M, Tolosa N, Salas P, Benitez J, Santos M, Malo DC, et al. Brote de enfermedad por virus Zika en el municipio de Turbaco. Inf Quinc Epidemiol Nac [Internet]. 2016;21(17). Available from: https://www.ins.gov.co/buscador-eventos/IQEN/IQEN vol 212016 num 17.pdf

84. Instituto Nacional de Salud (INS). Desnutrición aguda moderada y severa en menores de cinco años. Inst Nac Salud. 2019;

85. Moreno SL, Carreño PA. Lesiones de causa externa. Colombia 2011. Inst Nac Salud. 2012;13(1):11-64.

86. Instituto Nacional de Salud (INS). Informe anual red de donación y transplantes de Colombia, 2019. Inst Nac Salud [Internet]. 2019;2019. Available from: https://www.ins.gov.co/Direcciones/RedesSaludPublica/DonacionOrganosYTejidos/Estadisticas/infografia_red_nacional_de_donacion_y_trasplantes_20

87. Espitia NCC. Informe del comportamiento de VIH-SIDA, Colombia periodo epidemiológico del año 2016. Inst Nac Salud. $2019 ; 2$.

88. Instituto Nacional de Salud (INS). Accidente ofídico. Inst Nac Salud. 2020;

89. Varela SAGCAGAR. "Niveles de actividad física de la población Colombiana: Análisis por sexo y condición socioeconómica." Inst Nac Salud. 2013;1:10512.

90. Instituto Nacional de Salud (INS). Informe ejecutivo. Red de donación y transplantes de Colombia, 2018. Inst Nac Salud. 2019;

91. Paola S, Mora C. Accidente ofidico. Inst Nac Salud. 2019;

92. Instituto Nacional de Salud (INS). Malaria. Inst Nac Salud. 2021;

93. Instituto Nacional de Salud (INS). Parálsis flácida aguda colombia, 2019. Inst Nac Salud. 2019;

94. Instituto Nacional de Salud (INS). Bajo peso al nacer a termino. Inst Nac Salud. 2020;3:0-1.

95. Instituto Nacional de Salud (INS). Evento adverso posterior a la vacunación - grave. Inst Nac Salud. 2021;3-6.

96. Instituto Nacional de Salud (INS). Tétanos Neonatal Colombia 2018. Inst Nac Salud. 2018;

97. (INS) IN de S. Bajo Peso Al Nacer a Término. Inst Nac Salud [Internet]. 2018;PRO-R02.00:13. Available from:

http://www.dadiscartagena.gov.co/images/docs/saludpublica/vigilancia/protocolos/p2018/pro_bajo_peso_nacer_termino_2018.pdf

98. Instituto Nacional de Salud (INS). Brote de malaria en los municipios de Guapi y Timbiquí, Cauca, Colombia, 2014 Antecedentes. Inst Nac Salud [Internet]. 2014;2013:634. Available from: https://hsgm.saglik.gov.tr/depo/birimler/saglikli-beslenme-hareketli-hayat-db/Yayinlar/kitaplar/diger-kitaplar/TBSABeslenme-Yayini.pdf

99. Rivera S. Infecciones Asociadas a Dispositivos Colombia 2019. Inst Nac Salud [Internet]. 2019; Available from: https://www.ins.gov.co/buscadoreventos/Informesdeevento/INFECCIONES ASOCIADAS A DISPOSITIVOS_2019.pdf\#search=INFECCIONES ASOCIADAS A DISPOSITIVOS EN UCI

Page $18 / 25$ 
100. Instituto Nacional de Salud (INS). Infección Por Virus Del Zika En El Embarazo. Inst Nac Salud [Internet]. 2017;15:35. Available from:

https://uvadoc.uva.es/bitstream/handle/10324/24455/TFG-H886.pdf;jsessionid=8E0A6FD6E5C860F094BB8243AD8758D0? sequence=1

101. Instituto Nacional de Salud (INS). Tetanos accidental. Inst Nac Salud [INS]. 2020;

102. Instituto Nacional de Salud (INS). Endometritis puerperal. Inst Nac Salud. 2020;

103. Instituto Nacional de Salud (INS). Difteria. Inst Nac Salud. 2018;

104. Instituto Nacional de Salud (INS). Leptospirosis. Inst Nac Salud. 2020;

105. Instituto Nacional de Salud (INS). Leptospirosis. Inst Nac Salud. 2021;

106. Instituto Nacional de Salud (INS). Lepra. Inst Nac Salud. 2021;0-1.

107. Instituto Nacional de Salud (INS). Morbilidad Materna Extrema 2019. Boletín Epidemiológico Sem. 2019;

108. Instituto Nacional de Salud (INS). Mortalidad materna temprana. Inst Nac Salud. 2020;0-1.

109. Instituto Nacional de Salud (INS). Mortaludad materna temprana. Inst Nac Salud. 2021;2020-1.

110. Instituto Nacional de Salud (INS). Tétanos accidental. Inst Nac Salud. 2021;12-4.

111. Instituto Nacional de Salud (INS). Dengue. Inst Nac Salud. 2021;(1):19-22.

112. Instituto Nacional de Salud (INS). Dengue y COVID-19. Inst Nac Salud. 2020;

113. Instituto Nacional de Salud (INS). Dengue. Inst Nac Salud. 2018;

114. Instituto Nacional de Salud (INS). Chikungunya. Inst Nac Salud. 2020;

115. Instituto Nacional de Salud (INS). Sífilis congénita. Inst Nac Salud. 2021;2-4.

116. Instituto Nacional de Salud (INS). Fiebre tifoidea y embarazo. Inst Nac Salud. 2021;3(2):112-8.

117. Instituto Nacional de Salud (INS). Malaria. Inst Nac Salud. 2018;

118. Instituto Nacional de Salud (INS). Lepra. Inst Nac Salud. 2018;

119. Instituto Nacional de Salud (INS). Lepra. Inst Nac Salud. 2019;

120. Instituto Nacional de Salud (INS). Difteria. Inst Nac Salud. 2020;

121. Instituto Nacional de Salud (INS). Leptospirosis colombia, 2019. Inst Nac Salud. 2019;

122. Instituto Nacional de Salud (INS). Encefalitis equinas colombia, 2020. Inst Nac Salud. 2018;

123. Instituto Nacional de Salud (INS). Tracoma. Inst Nac Salud. 2019;

124. Instituto Nacional de Salud (INS). Chikungunya. Inst Nac Salud. 2018;

125. Instituto Nacional de Salud (INS). Fiebre amarilla [Internet]. Instituto Nacional de Salud (INS). [cited 2021 Mar 5]. Available from:

https://www.minsalud.gov.co/salud/publica/PET/Paginas/Fiebre-amarilla.aspx

126. Instituto Nacional de Salud (INS). Enfermedad por virus Zika (OPS/OMS). Inst Nac Salud. 2019;

127. Instituto Nacional de Salud (INS). Dengue. Inst Nac Salud. 2019;

128. Instituto Nacional de Salud (INS). Cáncer en menores de 18 años colombia, 2019. Inst Nac Salud. 2019;

129. Instituto Nacional de Salud (INS). Difteria. Inst Nac Salud. 2019;

130. Instituto Nacional de Salud (INS). Información receptores trasplantados de riñón con donante cadavérico ( DC ), Colombia 2016. Inst Nac Salud. 2017;

131. Instituto Nacional de Salud (INS). Defectos congénitos. Inst Nac Salud. 2018;

132. Instituto Nacional de Salud (INS). Eventos supuestamente atribuidos a la vacunacion o inmunizacion, Colombia. Inst Nac Salud. 2020;

133. Instituto Nacional de Salud (INS). Aumento inusitado de casos de malaria en Guainía, Colombia 2015 -2017. Inst Nac Salud. 2016;

134. Instituto Nacional de Salud (INS). Atribuidos a La Vacunación O Inmunización. Inst Nac Salud. 2017;

135. Instituto Nacional de Salud (INS). Sífilis congénita. Inst Nac Salud. 2020;0-1.

136. Instituto Nacional de Salud (INS). Intoxicaciones. Inst Nac Salud. 2018;

137. (INS) IN de S. Varicela. Inst Nac Salud. 2018;

138. Instituto Nacional de Salud (INS). Varicela. Inst Nac Salud. 2019;

139. (INS) IN de S. Tos ferina colombia, 2019. Inst Nac Salud. 2019;

140. Instituto Nacional de Salud (INS). Tos ferina. Inst Nac Salud. 2018;

141. (INS) IN de S. Tetantos accidental. Inst Nac Salud. 2019;

142. (INS) IN de S. Tetanos Neonatal. Inst Nac Salud. 2017;3(4):473-85.

143. Instituto Nacional de Salud (INS). Cáncer 2016. Inst Nac Salud. 2016;

144. Instituto Nacional de Salud (INS). Accidente ofídico. Inst Nac Salud. 2018;

145. Instituto Nacional de Salud (INS). SÍNDROME DE RUBÉOLA CONGÉNITA. Inst Nac Salud. 2018;

146. Instituto Nacional de Salud (INS). Brote de leishmaniasis visceral en área periurbana en el municipio de Neiva, Huila. Situación de enero a julio de 2017. Inst Nac Salud. 2012;(1):1-12.

147. Instituto Nacional de Salud (INS). Leishmaniasis Cutánea, Mucosa Y Visceral, Colombia 2018. Inst Nac Salud. 2019;05(31):28. 
148. Instituto Nacional de Salud (INS). Tracoma colombia 2017-2018. Inst Nac Salud [Internet]. 2018;13. Available from: https://www.ins.gov.co/buscadoreventos/Informesdeevento/TRACOMA_2018.pdf

149. Instituto Nacional de Salud (INS). Chagas (Agudo ). Inst Nac Salud. 2021;8-9.

150. (INS) IN de S. Mortalidad materna. Inst Nac Salud. 2019;100(6):555-63.

151. Instituto Nacional de Salud (INS). Fiebre amarilla. Inst Nac Salud. 2021;0-1.

152. Instituto Nacional de Salud (INS). Enfermedad por virus Zika. Inst Nac Salud. 2018;84(2).

153. Andrea L, Pinzón B. Tuberculosis Farmacorresistente Colombia, 2019. Inst Nac Salud [Internet]. 2020;1-33. Available from: https://www.ins.gov.co/buscador-eventos/Informesdeevento/TUBERCULOSIS FARMACORRESISTENTE_2019.pdf

154. Instituto Nacional de Salud (INS). Caso confirmado de chagas agudo, Rio Iro, Chocó. Inst Nac Salud. 2018;1-6.

155. Aranda-Torrelio E. Leishmaniasis visceral. Inst Nac Salud. 2021;53(5):246-9.

156. Instituto Nacional de Salud (INS). Sarampion y rubeola. Inst Nac Salud. 2018;

157. Zuluaga GPA, Alvarez-Lerma F. Determinantes económicos, sociales y de salud que inciden en la lactancia materna exclusiva en Colombia para el año 2010. Vol. 3, Universidad del Rosario. 2015.

158. Bonilla M, Campo A, Martínez M. Brote de malaria en el municipio de Quibdó Departamento del Chocó, Noviembre de 2015. Inf Quinc Epidemiológico Nac. 2016;21:17.

159. Campo Carey AR, Benavides Ocampo M, Martínez Durán ME, Caro Núñez OA, Gómez Amaya JA, Nieto Sánchez DL, et al. Brote de chikungunya en el municipio de Mahates, Bolivar, 2014. IQEN Inf Quinc Epidemiológico Nac. 2014;19(21):342-67.

160. Campo A, Martínez M, Benavides M, Cuellar N. Brote de chikungunya en el municipio de San Juan Nepomuceno, Bolivar, Colombia 2014. Inf Quinc Epidemiol Nac [Internet]. 2015;20(1):2-20. Available from: https://www.ins.gov.co/buscador-eventos/IQEN/IQEN vol 202015 num 1.pdf

161. Instituto Nacional de Salud (INS). Hepatitis B, hepatitis C y B delta. Inst Nac Salud. 2018;99(8):475.

162. Instituto Nacional de Salud (INS). Comportamiento Variables de interés. Inst Nac Salud. 2019;

163. Instituto Nacional de Salud (INS). Tétanos accidental. Inst Nac Salud. 2020;

164. Instituto Nacional de Salud (INS). Defectos congénitos. Inst Nac Salud. 2021;

165. Instituto Nacional de Salud (INS). Enfermedad de Chagas. Inst Nac Salud. 2019;14(1):9-13.

166. Instituto Nacional de Salud (INS). Enfermedades huerfanas - raras. Inst Nac Salud. 2020;

167. Instituto Nacional de Salud (INS). Sarampion y rubeola. Inst Nac Salud. 2020;

168. Instituto Nacional de Salud (INS). Sífilis gestacional. Inst Nac Salud. 2021;

169. Instituto Nacional de Salud (INS). Sífilis gestacional. Inst Nac Salud. 2020;0-1.

170. Instituto Nacional de Salud (INS). Defectos congénitos. Inst Nac Salud. 2020;0-1.

171. Instituto Nacional de Salud (INS). Mortalidad asociada a anomalías congénitas en Alcance y fuentes de esta conferencia. Inst Nac Salud. 2010;19982010.

172. Control VY, Publica ENS, Evento I. 2. introducción. Inst Nac Salud. 2015;

173. Instituto Nacional de Salud (INS). Comportamiento de Infección Respiratoria Aguda Semanas epidemiológicas 1 a 52 de 2012. Inst Nac Salud. 2012 ;

174. Instituto Nacional de Salud. Enfermedades huérfanas y raras. Inst Nac Salud. 2021;

175. Instituto Nacional de Salud (INS). Red de Donación y Trasplantes. Inst Nac Salud. 2020;

176. Instituto Nacional de Salud (INS). Procedimientos estéticos. Inst Nac Salud. 2021;12-4.

177. Instituto Nacional de Salud (INS). Leptospirosis. Inst Nac Salud. 2018;

178. Instituto Nacional de Salud (INS). Paralisis flacida aguda. Inst Nac Salud. 2018;

179. Instituto Nacional de Salud (INS). Desnutrición aguda moderada y severa en menores de cinco años. Inst Nac Salud. 2020;18-9.

180. Equipo maternidad segura - subdirección prevención vigilancia y control en salud pública. Mortalidad Perinatal y Neonatal Tardía. Protoc Vigil en salud pública [Internet]. 2018;1-19. Available from: https://www.ins.gov.co/buscador-eventos/Lineamientos/PRO Mortalidad perinatal neonatal.pdf

181. Espitia NCC. Informe del comportamiento de VIH-SIDA en Colombia, 2015. Inst Nac Salud. 2015;

182. Instituto Nacional de Salud INS. Tos ferina. Inst Nac Salud. 2021;

183. Instituto Nacional de Salud (INS). Evento adverso grave relacionado a inmunizaciones. Inst Nac Salud. 2020;0-1.

184. Instituto Nacional de Salud (INS). Hepatitis A. Inst Nac Salud. 2018;1-239.

185. Instituto Nacional de Salud (INS). Tuberculosis farmacorresistente. Inst Nac Salud [Internet]. 2019;0-1. Available from: https://www.ins.gov.co/buscadoreventos/Informesdeevento/TUBERCULOSIS FARMACORRESISTENTE PE II 2021.pdf

186. Instituto Nacional de Salud (INS). Protocolo Violencia de género e intrafamiliar. Inst Nac Salud. 2019;1-13.

187. Instituto Nacional de Salud (INS). Meningitis Bacteriana Y enfermedad meningococcica. Inst Nac Salud. 2020;

188. Instituto Nacional de Salud (INS). Informe anual Red de Donación y Trasplantes Colombia, 2008. Inst Nac Salud [Internet]. 2009; Available from: https://www.ins.gov.co/Direcciones/RedesSaludPublica/DonacionOrganosYTejidos/Estadisticas/INF COORD NAL MINPROT ORGANOS 2008.pdf

189. Instituto Nacional de Salud (INS). Parotiditis. Inst Nac Salud. 2018;

190. Instituto Nacional de Salud (INS). Desnutrición aguda moderada y severa en menores de cinco años. Inst Nac Salud. 2020;5-7.

Page $20 / 25$ 
191. Instituto Nacional de Salud (INS). Infecciones asociadas a procedimientos médico - quirúrgicos. Boletín epidemiológico Sem [Internet]. $2019 ; 25: 32$. Available from: https://www.ncbi.nlm.nih.gov/books/NBK536395/

192. Instituto de Medicina Legal y Ciencias Forenses. Lesiones De Causa Externa. Colombia, 2006. Inst Nac Salud [Internet]. 2018;11-34. Available from: https://www.medicinalegal.gov.co/documents/20143/49496/Contenido.pdf

193. Instituto Nacional de Salud. Mortalidad Perinatal y Neonatal. Boletín epidemiológico Sem [Internet]. 2019;30. Available from: https://www.ins.gov.co/buscador-eventos/BoletinEpidemiologico/2019 Boletín epidemiológico semana 12.pdf

194. Instituto Nacional de Salud. VIH, sida y muerte por SIDA. Colombia 2019. Inst Nac Salud [Internet]. 2019;22. Available from: https://www.ins.gov.co/buscador-eventos/Informesdeevento/VIH-SIDA_2019.pdf

195. Instituto Nacional de Salud (INS). Tétanos Accidental Colombia 2018. Inst Nac Salud [Internet]. 2018; Available from: https://www.dadiscartagena.gov.co/images/docs/saludpublica/vigilancia/protocolos/p2018/pro_tetanos_accidental_2018.pdf

196. Instituto Nacional de Salud. Agresiones y contactos con Animales Potencialmente Transmisores de Rabia y Rabia Humana. Inst Nac Salud [Internet]. 2019;1-4. Available from: http://www.ins.gov.co/buscador-eventos/Informesdeevento/VIGILANCIA INTEGRADA DE LA RABIA PE XIII 2018.pdf

197. Instituto Nacional de Salud. Sífilis Gestacional y Congénita 2018. Protoc Vigil en Salud Pública [Internet]. 2018;1-17. Available from: https://www.ins.gov.co/buscador-eventos/Lineamientos/PRO Sifilis_.pdf

198. Instituto Nacional de Salud (INS). Sarampión y Rubéola. Bol Epidemiol Sem 49 [Internet]. 2019;1-31. Available from: https://www.ins.gov.co/buscadoreventos/BoletinEpidemiologico/2019_Boletin_epidemiologico_semana_49.pdf

199. Instituto Nacional de Salud. Cáncer En Menores De 18 Años. Protoc en Vigil en salud publica [Internet]. 2017;1:19. Available from: https://www.ins.gov.co/buscador-eventos/Lineamientos/PRO Cáncer en menores de 18 años-.pdf

200. Instituto Nacional de Salud (INS). Paralisis Flácida Aguda. Inst Nac Salud. 2020;

201. Instituto Nacional de Salud. Infección Respiratoria Aguda. Inst Nac Salud [Internet]. 2016;2. Available from: https://www.minsalud.gov.co/sites/rid/Lists/BibliotecaDigital/RIDE/VS/PP/infeccion-respiratoria-aguda-ira-2016-.pdf

202. Instituto Nacional de Salud. Intoxicaciones por sustancias químicas. Inst Nac Salud [Internet]. 2018;51-104. Available from: http://www.vertic.org/media/assets/nim_docs/International Implementation Assistance Program (IAP) pdfs - CW/Chemical products/Chemical products Spanish.pdf

203. Instituto Nacional de Salud (INS). Exposición a Flúor. Inst Nac Salud. 2018;

204. Instituto Nacional de salud INS. Informe De Evento VIH/SIDA, Colombia, Año 2018. Inst Nac Salud. 2018;16.

205. Instituto Nacional de Salud. Ministerio de Salud de Colombia. Meningitis Bacteriana Y Enfermedad Meningocócica. Inst Nac Salud [Internet]. $2019 ; 1-17$. Available from: http://www.dadiscartagena.gov.co/images/docs/saludpublica/vigilancia/protocolos/p2018/pro_meningitis_2018.pdf

206. Instituto Nacional De Salud., Dirección Redes En Salud Pública., Subdirección Red Nacional De Trasplantes Y Bancos De Sangre., Coordinación Nacional Red Donación Y Trasplantes. Informe anual red de donación y trasplantes. Inst Nac Salud [Internet]. 2018;4-76. Available from: https://www.ins.gov.co/Direcciones/RedesSaludPublica/DonacionOrganosYTejidos/Estadisticas/Informe-Anual-Red-Donacion-Trasplantes-2018.pdf

207. Instituto Nacional de Salud (INS). Brote de evento de etiología desconocida en el municipio de El Carmen de Bolívar, Bolívar, 2014. Inst Nac Salud. 2014;II(441):1-40.

208. Instituto Nacional de Salud (INS). Leishmaniasis mucosa. Inst Nac Salud. 2021;

209. (INS) IN de S. Informe de Evento Desnutricion Aguda Moderada y Severa En Menores De Cinco Años. Inf del Even [Internet]. 2018;13. Available from: https://www.ins.gov.co/buscador-eventos/Informesdeevento/DESNUTRICIÓN AGUDA EN MENORES CINCO AÑOS SEMESTRE I 2018.pdf

210. Instituto Nacional de Salud (INS). Síndrome de rubeola congenita. Inst Nac Salud. 2019;

211. R4V. Situación y respuesta del fenómeno migratorio en salud. R4V. 2021;3-7.

212. R4V. Afiliaciones a la Salud de Refugiados y Migrantes Venezolanos - Antioquia. R4V. 2021;

213. Social. M de S y P. Informe de resultados: Estudio de evaluación de los servicios de las EPS por parte de los usuarios, en el régimen contributivo y subsidiado. Minist salud. 2014;7-24.

214. Cuenta de Alto Costo. Artritis reumatoide, una enfermedad que afecta la productividad laboral | Cuenta de Alto Costo [Internet]. Cuenta de Alto Costo. 2021 [cited 2021 Nov 20]. Available from: https://cuentadealtocosto.org/site/artritis/artritis-reumatoide-una-enfermedad-que-afecta-la-productividadlaboral/

215. Costo C de alto. Día mundial contra el cáncer 2020 | Cuenta de Alto Costo [Internet]. 2021 [cited 2021 Nov 20]. Available from: https://cuentadealtocosto.org/site/cancer/dia-mundial-contra-el-cancer-2020/

216. Deissy Agudelo. Mortalidad por desnutrición infantil en menores de 5 años y sus determinantes a nivel municipal en Colombia 1998 - 2016 . Univ Nac Colomb. 2019;

217. Trabajo MSB. Factores asociados a la morbilidad materna extrema a nivel individual y entre las comunas y corregimientos de Medellín, $2013-2015$. Occup Med (Chic III). 2017;53(4):130.

218. Romero Acosta DC. Factores asociados a la desigualdad de la Mortalidad Infantil en las localidades de Bogotá, 2013. Univ Nac Colomb [Internet]. 2017; Available from: https://repositorio.unal.edu.co/handle/unal/78391

219. Escobar OJV. Intervención de enfermería para el automanejo de adultos con cáncer colorrectal en tratamiento quirúrgico. Univ Nac Colomb [Internet]. 2020;211. Available from: https://repositorio.unal.edu.co/bitstream/handle/unal/78593/Tesis Final Oscar Vergara 5 Noviembre - 2020.pdf? sequence $=1$ \&isAllowed $=y$ 
220. Calderon Ramirez VA. Desigualdad en carga de enfermedad por Infección respiratoria aguda (IRA) y enfermedad diarreica aguda (EDA) menores de 5 aos, Colombia 2010. Univ Nac Colomb. 2016;55.

221. González LC. Determinantes Sociales y Mortalidad en menores de 5 años en el Departamento del Chocó Nota de aceptación de Manuscrito Título: Determinantes Sociales y Mortalidad en menores de 5 años en el Departamento del Chocó. Fac Nac Salud Pública. 2016;

222. Castañeda CN, Bacterióloga R, Clínico L. Asociación de la carga de enfermedad por Leucemia pediátrica aguda y las desigualdades en salud por régimen de afiliación y departamento de procedencia en Colombia durante el periodo 2011-2012. Univ Nac Colomb. 2016;27-30.

223. Forero LMN. Escala de vulnerabilidad de muerte por infección respiratoria aguda, en menores de un año, en Bogotá según determinantes sociales de la salud. Univ Nac Colomb. 2017;

224. Helena B, Mora S. Análisis cualitativo de las muertes maternas en Buenaventura $2010-2012$ con enfoque de determinantes sociales y equidad. Fac Nac Salud Pública. 2016;

225. Peñafiel JW. Caracterización de los pacientes con diagnóstico de cáncer de mama, en el Hospital de la Samaritana, Bogotá 2010 - 2018 . Univ Nac Colomb. 2020;

226. Barragan MM. Equidad en salud: estudio de caso en el distrito capital de Bogotá. Univ Nac Colomb. 2006;3:313-23.

227. Zamir M, Ibarguen T. Caracterización de la calidad del proceso de atención de pacientes con cáncer colorrectal atendidos en los años 2014 y 2015 en el Instituto Nacional de Cancerología E. S. E. MIGUEL. Fac Nac Salud Pública. 2020;

228. Enrique I, Puerta P, Enrique I, Cortés P, Caballero AD. Investigaciones originales research articles. Res Artic. 2018;8(1):60-74.

229. Patricia M, Mu B. Barreras de acceso al Programa Ampliado de Inmunizaciones, de la población infantil asistente a las casas vecinales de Tibabitá y Horizontes de la localidad de Usaquén, Bogotá D.C., año 2008. Univ Nac Colomb. 2008;

230. Jaimes- Acevedo JC. Caracterización sociodemográfica de la salud materna en el: una mirada desde la morbimortalidad. Univ Nac Colomb. 2019;20115.

231. Atehortúa S, Palacio-Mejía L. Impacto del seguro subsidiado en el acceso y el uso de servicios de salud: el caso de Medellín, Colombia. Lect Econ. 2015;16(82):522-33.

232. Rodríguez AYR. Caracterización de la mortalidad en personas de 30 y más años por enfermedades cardio-cerebrovasculares y su relación con aspectos socio-económicos y de vinculación al sistema general de seguridad social en salud. Colombia (2005-2013). Rev la Fac Med. 2017;26(4):219-27.

233. Almario-Barrera AJ, Villarreal-Neira C, Concha-Sánchez SC. Aspectos relacionados con el número de citas odontológicas a las que asisten las mujeres embarazadas en Santander. Rev la Fac Med. 2017;65(1):73-9.

234. Carrioni CAP. Caracterización del trauma maxilofacial en el Hospital la Samaritana de Bogotá entre los años 2008 a 2013. Univ Nac Colomb. 2015;3(7):59-78.

235. Ruiz-Rodríguez M, Vera-Cala LM, López-Barbosa N. Seguro de salud y cobertura de vacunación en población infantil con y sin experiencia de desplazamiento forzado en Colombia. Rev Salud Publica. 2008;10(1):49-61.

236. Por T, Vez P, Centros EN, En O, Periodo EL. Supervivencia de los pacientes con cáncer escamocelular bucal, tratados por primera vez, en centros oncológicos en el periodo 2000 a 2011, Medellín- Colombia. Rev Fac Odontol Univ Antioquia. 2016;27:245-61.

237. Suárez MGSG. Comparación de dos modelos de asesoría en anticoncepción para mujeres VIH positivas desde una perspectiva de equidad en salud Colombia 2015-2017. Fac Nac Salud Pública. 2019;

238. Rincón JMS. Factores asociados de la pobreza multidimensional con la toma de citología en Colombia. Univ del Rosario [Internet]. 2020;9(May):6. Available from: https://www.slideshare.net/maryamkazemi3/stability-of-

colloids\%0Ahttps://barnard.edu/sites/default/files/inline/student_user_guide_for_spss.pdf\%0Ahttp://www.ibm.com/support\%0Ahttp://www.spss.com/sit book/legacy/ProgDataMgmt_SPSS17.pdf\%0Ahttps://www.n

239. Garcia CS. Asociación entre condiciones sociodemográficas y epilepsia no controlada en poblaciones con acceso limitado a servicios de neurología. Univ del Rosario. 2019;8(5):55.

240. Garcia-Subirats I, Vargas I, Mogollón-Pérez AS, De Paepe P, da Silva MRF, Unger JP, et al. Barriers in access to healthcare in countries with different health systems. A cross-sectional study in municipalities of central Colombia and north-eastern Brazil. Soc Sci Med [Internet]. 2014;106:204-13. Available from: http://dx.doi.org/10.1016/j.socscimed.2014.01.054

241. Bouwmans M, Gaona MA, N Chenault M, Zuluaga C, Pinzon Rondon AM. Prevalence of intestinal parasitic infections in preschool-children from vulnerable neighborhoods in Bogotá. Rev la Univ Ind Santander Salud. 2016;48(2):178-87.

242. Palacios MS. Caracterización y perfiles de pacientes con morbilidad materna extrema, unidad de cuidados intensivos, hospital la samaritana, 2008 -2014. Univ del Rosario. 2017;2008-14.

243. Agudelo YRO. Salud sexual y reproductiva: aspectos de análisis para el departamento de Casanare. Appl Microbiol Biotechnol. 2016;85(1):2071-9.

244. Mora PED. Determinantes socio-económicas de la desnutrición global infantil en la localidad de ciudad Bolívar (Bogotá, Colombia) en el año 2011. Vol. 1, Universidad del Rosario. 2019.

245. Saboyá ELS, Giraldo MMLRFG. Determinantes sociales y su asociación con la no toma de citología cérvico vaginal en la población rural de Colombia. Univ del Rosario [Internet]. 2020;4(1):1-9. Available from: https://pesquisa.bvsalud.org/portal/resource/en/mdl20203177951\%0Ahttp://dx.doi.org/10.1038/s41562-020-0887-9\%0Ahttp://dx.doi.org/10.1038/s41562-020-0884z\%0Ahttps://doi.org/10.1080/13669877.2020.1758193\%0Ahttp://sersc.org/journals/index.php/IJAST/article

246. Díaz B LM, Chávez G BM. Complicaciones maternas en adolescentes y adultas afiliadas al régimen subsidiado, 2012. Rev Fac Nac Salud Pública. 2015;33(2). 
247. Barrientos MS. Factores asociados a la morbilidad materna extrema a nivel individual y entre las comunas y corregimientos de Medellín, $2013-2015$. Occup Med (Chic III). 2017;53(4):130.

248. Cifuentes MAP, Trabajo. atendidos por enfermedades crónicas no transmisibles en la E . S . E Hospital Pedro Claver Aguirre del municipio de ToledoAntioquia 2015-2019. María Alejandra Pérez Cifuentes Trabajo de grado para optar por el título de Profesional en Administración en. Univ Antioquia. 2021;

249. Viviana S, Ruiz H. Caracterización de las gestantes con Zika virus del municipio de Villavicencio, 2016. Univ los Andes. 2016;

250. Arenas Duque A, Lucumí DI. Caracterización del accidente cerebrovascular en Colombia. Ser Doc Trab 2019. 2019;7816(63).

251. Murcia Urrego LE. Determinantes sociales de la morbimortalidad infantil por Infección Respiratoria Aguda en Bogotá 2015-2016. Univ los Andes [Internet]. 2019; Available from: http://hdl.handle.net/1992/44267

252. García Villamizar SY. Análisis Descriptivo De La Morbimortalidad Por Leucemia Linfoide Aguda En Menores De 20 Años Según Departamento Y Régimen De Aseguramiento En Colombia 2010-2015. Univ del Bosque [Internet]. 2020;1-55. Available from:

https://repositorio.unbosque.edu.co/bitstream/handle/20.500.12495/2864/Garcia_Villamizar_Sandra_Yulitza_2020.pdf?sequence=12\&isAllowed=y

253. Mónica Alexandra Zúñiga Núñez. Desigualdades del aseguramiento en salud de la atención prenatal en Colombia Insurance health disparities in antenatal care in Colombia Autor: Univ del Bosque. 2018;(22).

254. Acevedo NE. Acceso a los servicios curativos de salud oral en escolares de la localidad de Fontibón de Bogotá D.C., 2009. Univ Javeriana. 2011;

255. Arrivillaga Quintero M, Zapata Ossa H, Tovar Cuevas LM, Correa Sánchez DE, Varela Arévalo MT, Hoyos Hernández PA. Infecciones de transmisión sexual en Colombia: análisis basado en la encuesta nacional de salud: año 2007. Vol. 10, Gerencia y Políticas de Salud. 2011.

256. Vergara ÓJ. Intervención de enfermería para el automanejo de adultos con cáncer colorrectal en tratamiento quirúrgico. 2020;211. Available from: https://repositorio.unal.edu.co/bitstream/handle/unal/78593/Tesis Final Oscar Vergara 5 Noviembre - 2020.pdf?sequence=1\&isAllowed=y

257. Posada López A, Palacio MA, Salas Z C, Álvarez M. E, Grisales H. Supervivencia de los pacientes con cáncer escamocelular bucal, tratados por primera vez, en centros oncológicos en el periodo 2000 a 2011, Medellín-Colombia. Rev Fac Odontol. 2016;27(2):245-61.

258. Instituto Nacional de Salud (INS). Desnutrición aguda, moderada y severa en menores de cinco años. Inst Nac Salud. 2020;5-7.

259. Instituto Nacional de Salud (INS). Enfermedades huérfanas y raras. Inst Nac Salud. 2021;

260. Instituto Nacional de Salud (INS). Red de Donación y Trasplantes. Informe 2021. Inst Nac Salud. 2021;

261. Instituto Nacional De Salud. Informe anual red de donación y trasplantes. Inst Nac Salud [Internet]. 2018;4-76. Available from: https://www.ins.gov.co/Direcciones/RedesSaludPublica/DonacionOrganosYTejidos/Estadisticas/Informe-Anual-Red-Donacion-Trasplantes-2018.pdf

262. Garcia CS. Asociación entre condiciones sociodemográficas y epilepsia no controlada en poblaciones con acceso limitado a servicios de neurología. Univ del Rosario. 2019;8(5):55.

263. Casallas, Juan Leonardo Novoa Garzón YTM. Evaluacion del tiempo libre de cisis de asma en niños de 4 a 11 años con relacion a factores sociales. Univ del Rosario [Internet]. 2019;9(1):148-62. Available from:

http://jurnal.globalhealthsciencegroup.com/index.php/JPPP/article/download/83/65\%0Ahttp://www.embase.com/search/results?

subaction=viewrecord\&from=export\&id=L603546864\%5Cnhttp://dx.doi.org/10.1155/2015/420723\%0Ahttp://link.springer.com/10.1007/978-3-319-76

264. Mora PED. Determinantes socio-económicas de la desnutrición global infantil en la localidad de ciudad bolívar (Bogotá, Colombia) en el año 2011. Univ del Rosario. 2012;13(April):15-38.

265. Barahona-Correa JE, Flórez-Suárez J, Coral-Alvarado P, Méndez-Patarroyo P, Quintana-López G. Does healthcare regime affiliation influence the clinical outcomes of patients with rheumatoid arthritis? Clin Rheumatol. 2021 Mar;40(3):877-86.

266. Garcés-Palacio IC, Altarac M, Kirby R, McClure LA, Mulvihill B, Scarinci IC. Contribution of health care coverage in cervical cancer screening follow-up: findings from a cross-sectional study in Colombia. Int J Gynecol cancer Off J Int Gynecol Cancer Soc. 2010 Oct;20(7):1232-9.

267. Afanador Echeverri GF, Ribero V. Current situation of migraine in Colombia: analysis based on the health services information system (RIPS). Value Heal [Internet]. 2019;22(Supplement 2):S286. Available from: http://ovidsp.ovid.com/ovidweb.cgi?

$T=J S \& P A G E=$ reference \&D=emed20\&NEWS=N\&AN=2002156783

268. Instituto Nacional de Salud (INS). Leptospirosis. Inst Nac Salud. 2015;

269. Instituto Nacional de Salud (INS). Tracoma. Inst Nac Salud. 2020;1-2.

270. Instituto Nacional de Salud (INS). Tracoma. Inst Nac Salud. 2020;1:105-12.

271. (INS) IN de S. Tetanos Neonatal. Inst Nac Salud. 2019;3(4):473-85.

272. (INS) IN de S. Tetanos accidental. Inst Nac Salud. 2019;

273. (INS) IN de S. Tetanos Neonatal. Inst Nac Salud. 2020;3(4):473-85.

274. Instituto Nacional de Salud (INS). Eventos graves supuestamente atribuidos a la vacunación o inmunización. Inst Nac Salud. 2018;

275. Instituto Nacional de Salud (INS). Accidente ofídico. Inst Nac Salud. 2021;

276. Instituto Nacional de salud (INS). Síndrome de rubeola congénita. 2018;

277. Instituto Nacional de Salud (INS). Sarampión y rubeola. Inst Nac Salud. 2018;

278. Instituto Nacional de Salud (INS). Sarampión y rubeola. Inst Nac Salud. 2020;

279. Instituto Nacional de Salud. Ministerio de Salud de Colombia. Meningitis Bacteriana Y Enfermedad Meningocócica. Inst Nac Salud [Internet]. $2019 ; 1-17$. Available from: http://www.dadiscartagena.gov.co/images/docs/saludpublica/vigilancia/protocolos/p2018/pro_meningitis_2018.pdf

280. Instituto Nacional de Salud (INS). Malaria Y Covid-19. Inst Nac Salud. 2021;

Page $23 / 25$ 
281. Botero DS. Informe final del evento leptospirosis, Colombia, 2015. Inst Nac Salud. 2015;3:103-11.

282. Instituto Nacional de Salud (INS). Fiebre amarilla. Inst Nac Salud. 2018;11(216):45.

283. Los Q, Con P. Leishmaniasis mucosa. 2021;

284. Instituto Nacional de Salud (INS). Enfermedad por virus Zika. Inst Nac Salud. 2021;84(2):17-9.

285. Instituto Nacional de Salud (INS). Encefalitis equinas colombia, 2020. Inst Nac Salud. 2020;

286. Instituto Nacional de Salud. Infección Respiratoria Aguda. Hnrg [Internet]. 2016;2. Available from:

https://www.minsalud.gov.co/sites/rid/Lists/BibliotecaDigital/RIDE/VS/PP/infeccion-respiratoria-aguda-ira-2016-.pdf

287. Instituto Nacional de Salud (INS). Enfermedad de Chagas. Prensa Med Mex. 1949;14(1):9-13.

288. Borrero E, Carrasquilla G, Alexander N. Decentralization and health system reform: what is their impact on malaria incidence in Colombian municipalities? Biomedica. 2012 Mar;32 Suppl 1:68-78.

289. Instituto Nacional de Salud (INS). Sífilis Gestacional y Congénita 2018. Protoc Vigil en Salud Pública [Internet]. 2018;1-17. Available from: https://www.ins.gov.co/buscador-eventos/Lineamientos/PRO Sifilis_.pdf

290. Instituto Nacional de Salud (INS). Morbilidad Materna Extrema 2019. Boletín Epidemiológico Sem. 2018;

291. Alvarez-Bravo A. Mortalidad materna. Gac Med Mex. 1970;100(6):555-63.

292. (INS) IN de S. Infecciones asociadas a procedimientos médico - quirúrgicos. Boletín epidemiológico Sem [Internet]. 2019;25:32. Available from: https://www.ncbi.nlm.nih.gov/books/NBK536395/

293. Yepes FJ, Gómez JG, Zuleta JJ, Londoño JL, Acosta-Reyes JL, Sánchez-Gómez LH, et al. Healthcare and maternal morbidity and mortality: a hospitalbased case-control study in two regions of Colombia (Bogotá and Antioquia), 2009-2011. Cad Saude Publica. 2016 Nov;32(11):e00080215.

294. Instituto Nacional de Salud (INS). Bajo Peso Al Nacer a Término. Inst Nac Salud [Internet]. 2017;PRO-R02.00:13. Available from: http://www.dadiscartagena.gov.co/images/docs/saludpublica/vigilancia/protocolos/p2018/pro_bajo_peso_nacer_termino_2018.pdf

295. (INS) IN de S. Bajo Peso Al Nacer a Término. Inst Nac Salud [Internet]. 2017;PRO-R02.00:13. Available from: http://www.dadiscartagena.gov.co/images/docs/saludpublica/vigilancia/protocolos/p2018/pro_bajo_peso_nacer_termino_2018.pdf

296. Jimenez M angel C. Mortalidad asociada a anomalías congénitas en Alcance y fuentes de esta conferencia. 2010.

297. Houweling TAJ, Arroyave I, Burdorf A, Avendano M. Health insurance coverage, neonatal mortality and caesarean section deliveries: an analysis of vital registration data in Colombia. J Epidemiol Community Health [Internet]. 2017;71(5):505-12. Available from: http://ovidsp.ovid.com/ovidweb.cgi? $T=J S \& P A G E=$ reference $\& D=$ med $14 \& N E W S=N \& A N=27669713$

298. Moreno SL, Carreño PA. Lesiones de causa externa. Colombia, 2011. Forensis. 2012;13(1):11-64.

299. (INS) IN de S. Procedimientos estéticos. Lesiones de causa externa. Inst Nac Salud. 2021;12-4.

300. Instituto Nacional de Salud (INS). Intoxicaciones por sustancias químicas. Inst Nac Salud [Internet]. 2018;51-104. Available from: http://www.vertic.org/media/assets/nim_docs/International Implementation Assistance Program (IAP) pdfs - CW/Chemical products/Chemical products Spanish.pdf

301. EMSANAR E. Caracterización de pacientes afiliados a la Empresa Promotora de Salud del Régimen Subsidiado (EPS-S)“EMSSANAR.” EMSSANAR. 2015;

302. Gomez de la Rosa F, Marrugo-Arnedo CA, Florez-Tanus Á, López-Pájaro K, Mazenett-Granados E, Orozco-Africano J, et al. Impacto económico y sanitario del control prenatal en embarazadas afiliadas al régimen subsidiado en Colombia durante 2014. Salud Publica Mex [Internet]. 2017 Mar 31 [cited 2021

Sep 24];59(2):176. Available from: http://www.saludpublica.mx/index.php/spm/article/view/7766

303. López JEB. Características de los cuidadores asociadas a la consulta odontológica de niños colombianos menores de 5 años. Univ del Rosario. 2019;1:105-12.

\section{Figures}




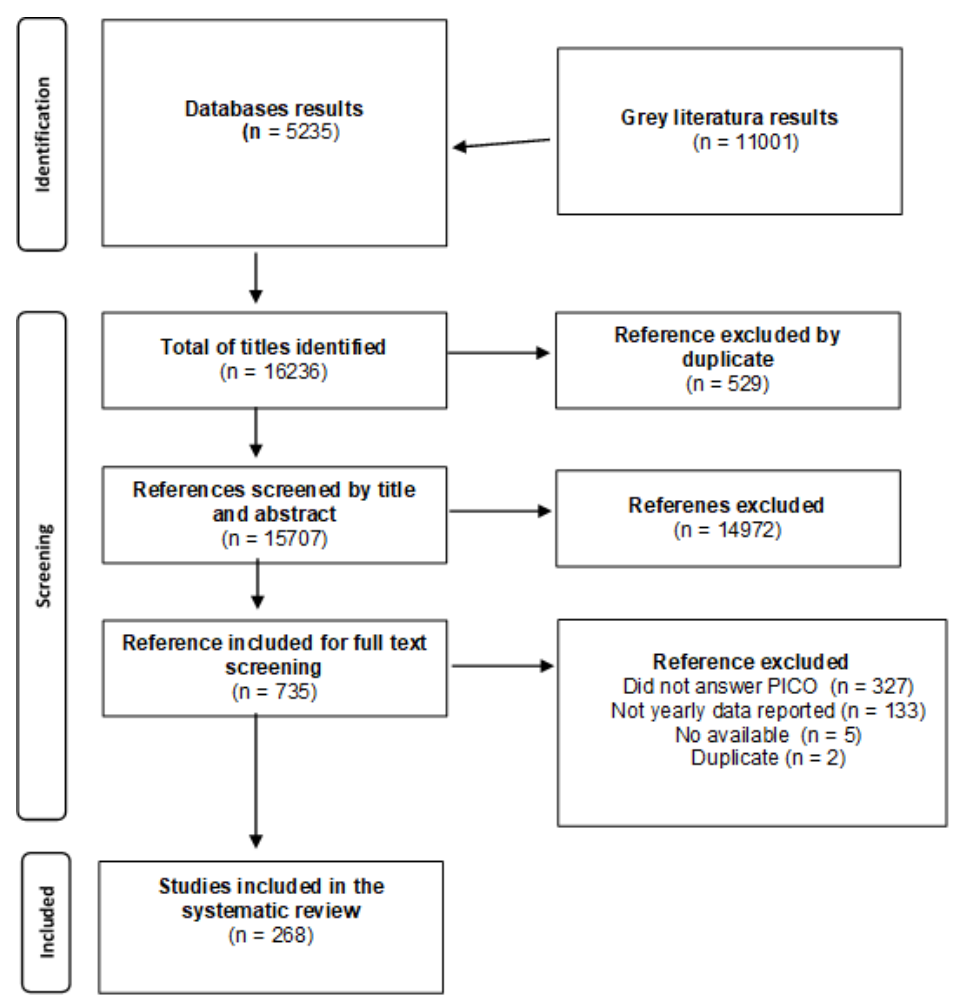

\section{Figure 1}

Preferred Reporting Items for Systematic Reviews and Meta-Analyses (PRISMA) Diagram

\section{Supplementary Files}

This is a list of supplementary files associated with this preprint. Click to download.

- Aditionalfile1.docx

- Additionalfile2.docx

- Additionalfile3.docx

- Additionalfile4.docx 